\title{
BIAS IN THE BOARDROOM: PSYCHOLOGICAL FOUNDATIONS AND LEGAL IMPLICATIONS OF CORPORATE COHESION*
}

\author{
James D. Cox $\dagger$ \\ AND \\ HARRY L. MUNSINGER**
}

\section{INTRODUCTION}

Critics have long recognized the powerful incentives driving managers of public corporations to pursue personal rewards to the detriment of the firm's owners. ${ }^{1}$ Those concerned with reforming the errant ways of the public corporation's management have frequently included independent directors among their prescriptions: The independent directors are to monitor the managers and curb their most serious departures from the desired goal of maximizing shareholder wealth. ${ }^{2} \mathrm{~A}$ tacit assumption of the monitoring model is that the independent directors will not themselves be corrupted by a quest

Copyright $\odot 1985$ by James D. Cox

* The authors are grateful for the suggestions made by Professors David Carlson, John Payne, and Joyce Rutledge in their review of an earlier draft of this article.

$\dagger$ Professor of Law, Duke University.

** Formerly Associate Professor of Psychology, University of California at San Diego; J.D., Duke University, 1984; Ph.D., Psychology, University of Oregon.

1. This divergence was given popular attention in the classic A. Berle \& G. Means, The Modern Corporation and Private Property (1932), and is established with some theoretical rigor in Jensen \& Meckling, Theory of the Firm: Managerial Behavior, Agency Costs and Ownership Structure, $3 \mathrm{~J}$. FIN. ECON. 305 (1976); the conclusion is strengthened by findings in a new economic discipline generally referred to as agency theory. See, e.g., Fama, Agency Problems and the Theory of the Firm, $88 \mathrm{~J}$. POL. ECON. 288 (1980); Holmstrom, Moral Hazard and Observability, 10 BELl. J. ECON. 74 (1979); Ross, The Economic Theory of Agency: The Principal's Problems, Am. Econ. Rev. PAPers \& Proc., May 1973, at 134; see also Alchian \& Demsetz, Production, Information Costs, and Economic Organization, 62 AM. EcoN. REv. 777 (1972); Spence \& Zeckhauser, Insurance, Information, and Individual Action, AM. Econ. Rev. Papers \& Proc., May 1971, at 380. See generally Symposium, Corporations and Private Property, 26 J. L. \& Econ. 235-496 (1983).

2. This notion is the touchstone for the current proposals to the American Law Institute. See Principles of Corporate Governance: Analysis and Recommendations Part III (Tent. Draft No. $2,1984)$. The reporter for those provisions of the ALI's corporate governance project which are concerned with the directors' duty to monitor has based his premise upon what he believes the directors are capable of doing, not what they in fact accomplish. See Eisenberg, Legal Models of Management Structure in the Modern Corporation: Officers, Directors, and Accountants, 63 CALIF. L. REv. 375 (1975). See generally Eisenberg, The Legal Roles of Shareholders and Management in Modern Corporate Decisionmaking, 57 CaLIF. L. REv. 1 (1969). The findings of this article do not support the belief that boardroom colleagues can effectively monitor one another to the degree prescribed in the proposals to the ALI. 
to maximize their own utility at the shareholders' expense. ${ }^{3}$ Indeed, the monitoring model appears to be premised upon the unsubstantiated belief that direciors who are neither economically dependent upon the firm or its managers, ${ }^{4}$ nor enriched by a particular transaction, ${ }^{5}$ will be faithful guardians of the corporation's interest, or will allow only trivial departures by management from the corporation's and shareholders' economic interest.

Serious mistrust has been expressed concerning the independent directors' ability to discharge this monitoring function. ${ }^{6}$ In this article we offer a psychological perspective on a specific application of the monitoring function: the independent directors' assessment whether the corporation's interest is served by a derivative suit against their "insider" colleagues. The independent directors' assessment conventionally occurs in response to a demand made upon the directors through derivative suit procedures. ${ }^{7}$ Recently, independent directors have acted through special litigation committees, often empanelled after a demand upon the full board has been excused because the suit implicated a majority of the directors in the alleged wrongdoing. ${ }^{8}$ The committee evaluates the derivative suit's impact on the corporation's interests and submits to the court its opinion whether these interests are advanced by the suit's continuance.

We are interested in the independent directors' ability to perceive and represent the corporate interest in evaluating a demand to the board or in serving on a special litigation committee. We examine several social-

3. See, e.g., Haft, Business Decisions by the New Board: Behavioral Science and Corporate Law, 80 MICH. L. REV. 1,19 (1981).

4. See, e.g., M. Eisenberg, The Structure of the Corporation: A Legal Analysis $170-85$ (1976), wherein the attachments sought to be removed in providing independence are those of an economic nature. See also Principles of Corporate Governance, supra note 2, § 3.04, which recommends that a majority of the board of a large public corporation be independent; independence is defined in terms of familial or economic ties to the corporation or its senior executives. Id. $\S 1.26$.

5. This belief is at the heart of the validating effect of "disinterested" director approval common to state conflict of interest statutes. See, e.g., CAL. Corp. Code $\$ 310(a)(2)$ (West 1977); Del. Code ANN. tit. 8, § 144(a)(1) (1983); N.Y. Bus. CoRP. LAW § 713(a)(1) (McKinney Supp. 1983-84); Model Business CORP ACT $\$ 41$ (1971 \& Supp. 1977). Upon approval by disinterested directors, the presumption of propriety and fair dealing is returned to the otherwise self-dealing transaction. See $\mathbf{E}$. Folk, The Delaware General Corporation Law 82-86 (1972); Israels, The Corporate Triangle-Some Comparative Aspects of the New Jersey, New York, and Delaware Statutes, 23 RuTcers L. REv. 615, 627-28 (1969); $c f$. Buxbaum, Conflict-of-Interests Statutes and the Need for a Demand on Directors in Derivative Actions, 68 CALIF. L. REv. 1122 (1980) (presumption is often, but not always returned).

6. See Brudney, The Independent Director-Heavenly City or Potemkin Village, 95 HaRv. L. REv. 597 (1982); Solomon, Restructuring the Corporate Board of Directors: Fond Hope-Faint Promise?, 76 Mich. L. Rev. 581 (1978); Werner, Corporation Law in Search of Its Future, 81 Colum. L. Rev. 1611, 1663.66 (1981).

7. See generally Note, The Demand and Standing Requirements in Stockholder Derivative Actions, 44 U. Chi. L. Rev. 168, 169-91 (1976).

8. See generally Cox, Searching for the Corporation's Voice in Derivative Suit Litigation: A Critique of Zapata and the ALI Project, 1982 Duke L. J. 959; Coffee, Beyond the Shut-Eyed Sentry: Toward a Theoretical View of Corporate Misconduct and an Effective Legal Response, 63 VA. L. REv. 1099, $1199-1208$ (1977); Dent, The Power of Directors to Terminate Shareholder Litigation: The Death of the Derivative Suit?, $75 \mathrm{Nw}$. U.L. REv. 96 (1980); Note, The Business Judgment Rule in Derivative Suits Against Directors, 65 CoRNELL L. Rev. 600 (1980); Comment, A Procedural Treatment of Derivative Suit Dismissals by Minority Directors, 69 Calif. L. Rev. 885 (1981). 
psychological mechanisms that can generate bias in the directors' assessment of the suit, including biases established by appointment of members to the board or a special litigation committee, control of pecuniary or nonpecuniary rewards made available to the independent directors by the defendant members of the board of directors, the independent directors' prior associations with the defendants, and their common cultural and social heritages. We conclude that, in combination, these several psychological mechanisms can be expected to generate subtle, but powerful, biases which result in the independent directors' reaching a decision insulating colleagues on the board from legal sanctions. In the final section, we offer a structural reform to neutralize these biases when evaluating the independent directors' recommendation.

\section{II}

\section{Social and Psychological Causes of Director Bias}

\section{A. Uncertainty and Director Bias}

This section describes the normative process by which directors should evaluate a derivative suit's impact upon the corporation's interests as well as the psychological mechanisms that deflect the directors' consideration of the suit's potentially beneficial effects. The theory advanced here is that directors edit the decision choices posed by the derivative suit in a manner which precludes consideration of the suit's favorable effects. Editing is a welldocumented approach decisionmakers utilize to simplify and reduce to manageable proportions inherently complex decisions. ${ }^{9}$ The near perfect record of defendants before special litigation committees ${ }^{10}$ suggests that such independent directors engage in editing. As a consequence of editing, the directors' evaluation of the suit is made, not in response to the corporation's interests, but as a result of the directors' social and psychological drives.

1. Risk Analysis. Litigation is an uncertain event; any proper description or evaluation of a suit's worth therefore covers an array of its possible outcomes as well as the probability of each outcome. ${ }^{11}$ Courts historically have been deferential to the directors' dismissal recommendation, so that the directors' arraying of the outcomes and their associated probabilities is not examined; courts instead limit their review to superficial questions about the directors' independence and good faith. ${ }^{12}$ To be sure, the case law reflects an outward concern that the directors' recommendation on the derivative suit's fate must

9. See infra text accompanying notes 19-33.

10. See infra text accompanying note 187 and cases cited infra note 97.

11. See, e.g., Joy v. North, 692 F.2d 880, 892-93 (2d Cir. 1982), cert. denied, 460 U.S. 1051 (1983).

12. See, e.g., Abramowitz v. Posner, 672 F.2d 1025, 1033 (2d Cir. 1982); Stein v. Bailey, 531 F. Supp. 694, 693-96 (S.D.N.Y. 1982). Factors considered in this inquiry are similar to those evaluated in determining whether a demand should be excused. See generally Note, The Demand and Standing Requirements in Stockholder Derivative Actions, 44 U. CHI. L. REv. 168, $173-82$ (1976). 
serve the corporate interest. ${ }^{13}$ In practice, however, courts fail to examine the propriety of heuristics utilized by "independent" directors in making their evaluation. For this reason, the case law exhibits no normative view of how reasonably objective directors should respond to a suit that has both upside potential and downside risk. Indeed, the record of litigation in this area suggests to the casual observer that derivative suits lack upside potential, because courts uncritically accept the directors' assessment that the suits have only negative effects. This judicial passivity also explains the absence of any well-developed notions of what standards are suitable for judging director evaluations of a suit's worth.

The corporate interest, even though a loosely defined concept, ${ }^{14}$ may nonetheless be identified using the normative economic view that an entity appropriately seeks to maximize its expected utility. Under this approach, generally known as expected utility theory, ${ }^{15}$ decisions made under uncertainty are rational if for any given level of risk they maximize expected returns (defined as the sum of the products of the outcomes and their probabilities of occurrence) and if they minimize the risk between equivalent expected returns. ${ }^{16}$ The utility-maximizing choice is one which is, by this

13. See, e.g., Lewis v. Curtis, 671 F.2d 779, 786 (3d Cir.), cert. denied, 459 U.S. 880 (1982); Gaines v. Haughton, 645 F.2d 761, 771 (9th Cir. 1981), cert. denied, 454 U.S. 1145 (1982); Abbey v. Control Data, 603 F.2d 724, 729-30 (8th Cir. 1979), cert. denied, 444 U.S. 1017 (1980); Cramer v. G.T.E., 582 F.2d 259, 272 (3d Cir. 1978), cert. denied, 439 U.S. 1129 (1979).

14. See, e.g., Principles of Corporate Governance, supra note 2 , $\$ 2.01$.

15. The leading work on expected utility theory remains J. von NewmanN \& O. MORGENSTERN, Theory of Games and Economic Behavior (1944).

16. To illustrate, assume a derivative suit alleging a director diverted corporate business to himself. Continuation of the derivative suit offers a $20 \%$ probability the net recovery will be $\$ 500,000$, a $40 \%$ probability the corporation will gain $\$ 100,000$, and a residual $40 \%$ chance no recovery will be made; moreover, the corporation will incur $\$ 400,000$ in direct and indirect costs in connection with pursuing the suit. On the other hand, should the directors recommend dismissal of the derivative suit, their decision will be upheld by the court under the applicable law. This choice of rejection, however, entails costs of $\$ 20,000$ - the attorney fees for submitting the directors' decision and briefing the court on the relevant authorities. Finally, we assume that the cost of the directors' evaluation is unaffected by which alternative is selected.

The decision to continue the suit has an expected value of $-\$ 20,000$, determined as follows:

\begin{tabular}{|c|c|c|}
\hline Outcome & Probability & $\begin{array}{c}\text { Outcome Weighed } \\
\text { by Probability }\end{array}$ \\
\hline $\begin{array}{r}\$ 500,0 \\
-\$ 100,0 \\
-\$ 400,0\end{array}$ & $\begin{array}{c}20 \% \\
40 \% \\
40 \% \\
\text { Expected value }\end{array}$ & $\begin{array}{r}\$ 100,000 \\
\$ 40,000 \\
-\$ 160,000 \\
-\$ 20,000\end{array}$ \\
\hline
\end{tabular}

Dismissal of the suit also has a value of $-\$ 20,000$, the cost of preparing the required motion.

According to common assumptions under expected utility theory, managers will prefer to seek dismissal, because between competing opportunities presenting the same expected return, the one with less risk should be preferred. In the example, a decision to continue is riskier because it presents a range of outcomes $(\$ 500,000$ gain to a $\$ 400,000$ loss) compared with a certain loss of $\$ 20,000$ upon dismissal. Another fundamental assumption of expected utility theory is that all persons are risk averse so that as between choices posing the same expected return, the choice having greater certainty is preferred; and as between choices of the same risk, the one with the higher expected return is preferred. Furthermore, even when the riskier choice has a greater expected return, that choice would not be embraced by the rational man if its expected return offers insufficient compensation for the risk. For example, if the decision to continue embodies an expected value 
definition, rational and which also reflects the entity's aversion to assuming risk. If reference were made to utility theory for a normative view of how directors should properly evaluate suits against their colleagues, then courts would be forced to choose between commonly held assumptions about decisionmakers' evaluation of risky choices in this regard and what appears to be their actual practice.

There is a clean divergence between theory and practice respecting whether managers are risk averse or risk seeking. ${ }^{17}$ Empirical evidence, contrary to widely held assumptions that managers are risk averse, reveals that managers are both risk averse and risk seeking. Their aversion to or preference for risk depends upon the outcomes of choices in relation to a "target point." 18 When all potential outcomes surpass a target point such as a desired rate of return, managers conform to the widely held assumption of risk aversion and select the less risky choice. ${ }^{19}$ Managers are risk preferring, however, whenever most of the outcomes posed by the choices fall below the target point, as long as at least one choice has an outcome above the target point. In this case, the managers' tendency is to prefer the choice which affords a chance, however slight and whatever the risk, of meeting or

of $\$ 100,000$ (against a certain loss of $\$ 20,000$ by discontinuance), continuance is wise only if the $\$ 100,000$ expected return is higher than competing opportunities for investment.

17. A wealth of empirical evidence indicates that expected utility theory fails to capture the complexities involved in making risky choices. For an excellent review of the studies, see Schoemaker, The Expected Utility Model: Its Variants, Purposes, Evidence and Limitations, 20 J. Econ. LrT. 529 (1982).

18. A consistent body of research has repeatedly shown the important role of a target point in the evaluation of risky choices. See, e.g., Payne, Laughhunn \& Crum, Further Tests of Aspiration Level Effect in Risky Choice Behavior, 27 Mgmr. Scr. 953 (1981) [hereinafter cited as Payne, Laughhunn \& Crum, Further Tests]; Payne, Laughhunn \& Crum, Translation of Cambles and Aspiration Level Effects in Risky Choice Behavior, 26 MGmT. SCI. 1039 (1980) [hereinafter cited as Payne, Laughhunn \& Crum, Translation]. See also Holthausen, A Risk-Return Model with Risk and Return Measured as Deviations from a Target Return, AM. ECON. REv., March 1981, at 182 (risk associated only with below-target outcomes). That decisions under uncertainty would be made by reference to a neutral target point was first suggested by Kahneman \& Tversky in Prospect Theory: An Analysis of Decision Under Risk, 47 ECONOMETRICA 263 (1979), and by Fishburn in Mean-Risk Analysis with Risk Associated with Below-Target Returns, Am. Econ. Rev., March 1977, at 116, although the more general notion of managers seeking suboptimal results that "satisfice" was suggested by $\mathrm{H}$. Simon in his classic book, Models of MaN $241-73$ (1957).

A target point can be an expected level of income, a desired rate of return, or merely the status quo. The research data show that decisions are reached by first classifying the outcomes of each choice as gains or losses in terms of whether the outcome is above or below the target point. In this way, an expected value of a law suit's continuance of $\$ 100,000$ may nevertheless be characterized as a loss because the rate of return on the corporate time and money expended in the suit is below the firm's traditional target return. The importance of the target point, and the characterization of expected outcomes as gains or losses by reference to the target point, suggest that the target point is a boundary around which attitudes toward risk change.

19. When expected values are above the target point, decision-makers are risk averse. See Payne, Laughhunn \& Crum, Further Tests, supra note 18, at 954. For example, they tend to prefer the choice with the least downside risk, and they show a strong aversion to any choice that includes an outcome below target compared with an alternative whose outcomes are all above target. Id.; see also Payne, Laughhunn \& Crum, Translation, supra note 18. Furthermore, among choices whose outcomes are all above the target point, they show a strong tendency to prefer the choice having the highest minimum outcome, even though other choices present a greater expected value. 
surpassing the target point. ${ }^{20}$ Such evidence implies that, to the extent independent directors share the risk preference of managers, their evaluation of derivative suits will be biased against continued litigation if they are directors of successful firms whose profits and rates of return exceed a satisfactory target level. These directors may be institutionally biased against a suit even though it has strong upside potential, because the magnitude of the gains are modest in comparison with those to be garnered in other areas of the firm's activities, and because, having exceeded their target, they are naturally risk averse. Directors of failing companies, on the other hand, might be expected to prefer the risk of continued litigation. What we in fact observe, however, is that even directors of failing enterprises systematically consider only downside potential, even in suits which offer the possibility of considerable upside gain. ${ }^{21}$

2. Choice Editing. Natural aversion toward risk can hardly explain the consistent behavior of directors in seeing only downside potential in derivative suits. A possible explanation may be found in natural forces that arise in decisionmaking, whereby individuals seek to keep an inherently complex problem within their limited processing capacity. When confronted by a multifaceted, inherently complex choice such as the choice to continue or terminate a derivative suit, decisionmakers edit the problem by simplifying the information relied upon to make a choice. ${ }^{22}$ The most frequent form of editing entails evaluating a current problem in terms of the decisionmakers' prior experience, understanding, or belief respecting problems of that same general type. ${ }^{23}$ Important bias is introduced by such simplifications because

20. On the other hand, managers are risk seeking when each choice has an expected value below the target point. Payne, Laughhunn \& Crum, Managerial Risk Preferences for Below-Target Returns, 26 Mgmt. Scr. 1238 (1980). See generally Fishburn \& Kochenberger, Two-Piece Von Neumann-Morgenstern Utility Functions, 10 Decision Sci. 503, 517 (1979); Hershey \& Schoemaker, Risk Taking and Problem Context in the Domain of Losses: An Expected Utility Analysis, $47 \mathrm{~J}$. Rısk. INs. 111 (1980); Schoemaker \& Kunreuther, An Experimental Study of Insurance Decisions, 46 J. Risk \& INs. 603 (1979).

The illustration, supra note 16, poses a case in which each choice's mean expected return is below the expected target point so that managers may be expected to be risk seeking, assuming the derivative suit decision were viewed in isolation.

21. See, e.g., Joy v. North, 692 F.2d 880 (2d Cir. 1982), cert. denied, 460 U.S. 105 I (1983).

22. See generally Payne, Contingent Decision Behavior, 92 Psych. Bull. 382 (1982). Complexities are introduced not only by the number of alternatives available, such as continuance, settlement, or dismissal, but also by the number of outcomes for each alternative, the time constraints, and the substance of the problem. It is interesting that heightened aversion to risk occurs as the time for making a decision is shortened. See, e.g., Wright, The Harassed Decision Maker: Time Pressures, Distraction and the Use of Evidence, $59 \mathrm{~J}$. Applied Psycholocy 555 (1974). Furthermore, risk aversion increases as the consequences of an outcome are experienced immediately rather than in the future. See Wright \& Weitz. Time Horizon Effects on Product Evaluation Strategies, 14 J. Marketing Research 429 (1977). See also Hogarth, Beyond Discrele Biases: Functional and Dysfunctional Aspects of Judgmental Heuristics, 90 PsYCH. Bull. 197 (1981). For an expanded discussion of the many variables which interdict normative decisionmaking as prescribed by expected utility theory, see D. Kahneman, P. Slovic \& A. Tversky, Judgment Under Uncertainty: Heuristics and Biases (1982).

23. See generally Fischoff, Hindsight Foresight: The Effect of Outcome Knowledge on Judgment Under lincertainty, 1 J. Experimental Psychology: Perception and Performance 288, 292-93 (1975) (reporting outcome increases perceived probability of event); Kahneman \& Tversky, Subjective Probability: A Judgment of Representativeness, 3 Cognitive Psychology 430 (1972); Lichtenstein, Slovic, Fischoff, Layman \& Combs, Judged Frequency of Lethal Events, 4 J. Experimental Psychology: Human 

affect their estimations of the suit's potential outcomes and their associated probabilities. ${ }^{29}$ Certainly there is a well-documented tendency among decisionmakers to engage in a good deal of "wishful thinking" when formulating such estimates ${ }^{30}$ for the perfectly understandable reason that differences in motivation will influence one's cognitive appreciation of an outcome's likely occurrence. Those outcomes that satisfy the decisionmaker's needs will be assigned a higher probability of occurrence than a less desired or unwanted outcome.

The most sweeping form of editing a complex, risky choice occurs through the decisionmakers' consideration of the collateral consequences of an outcome and the decisionmakers' special needs or circumstances. That is, the derived value to decisionmakers of a risky choice will not reflect solely the decisionmakers' attitudes toward its monetary effect. Any decision under uncertainty is necessarily made more complex by the presence of additional consequences which attach to one of its possible outcomes. In the context of business decisionmaking, if a sales manager needs only an additional $\$ 100,000$ in sales to earn a large bonus, there will be a steep rise in his utility function around the business choice which includes among its outcomes a $\$ 100,000$ increase in sales. This incentive makes itself felt by a subconscious assignment of more weight to that outcome than its magnitude would


consequence is negative, such as one of the choices including an outcome with a loss of $\$ 100,000$, which would entail the collateral effect that the manager will lose his job. Some outcomes, such as that just described, are so personally ruinous that the decisionmaker will edit the problem in a way that the choice embodying the ruinous outcome is eliminated from further consideration. ${ }^{32}$ The editing out of "ruinous loss" is therefore the ultimate tool employed to simplify complex problems.

The near perfect record of derivative suit defendants before their boards or committees ${ }^{33}$ is statistically so unexpected as to suggest that the defendants' colleagues have simplified the complex decision by editing the choices to foreclose further consideration of the choice to continue suit. Such a reaction is more likely to occur where the repercussions accompanying a decision to continue suit against a colleague threaten the reward structure linking the director and his corporate position, which is of great importance to satisfying the director's social needs. The next section offers insight into

29. See infra text accompanying notes 34-72.

30. See Yaari, Convexity in the Theory of Choice Under Risk, 79 Q. J. ECoN. 278, 290 (1965); P. Slovic, Value as a Determiner of Subjective Probability, IEeE Transactions on Human Factors in Electronics (1966); Irwin, Stated Expectations as Functions of Probability and Desirability of Outcomes, 21 J. Personality 329 (1953); Marks, The Effect of Probability, Desirability, and 'Privilege' on the Stated Expectations of Children, 19 J. Personality 332, $341-44$ (1951); see also Rossett, Weak Experimental Verification of Expected Utility Hypothesis, 38 Rev. Econ. STUd. 481, 487-89 (1971) (supporting Yaari's hypothesis).

31. See Kahneman \& Tversky, supra note 18 , at 277-80.

32. See Payne, Laughhunn \& Crum, supra note 20, at 1245-46.

33. See supra note 10. 
the relationship between directors' social needs and their service on corporate boards. The evidence amassed strongly suggests that a director's evaluation of a colleague's behavior is more likely to be dictated by the director's social or psychological drives than by the corporate interest.

\section{B. Social Needs and Director Service}

The leading criterion for selecting a board nominee is his probable identification with and acceptance of the company's goals and methods of operation. ${ }^{34}$ This selection criterion reflects the goal that boards of directors include executives of other corporations, who can be relied upon to know and understand the chief executive officer's problems in managing a company. ${ }^{35}$ The corporate executive's background also includes knowledge and experience that are believed to be necessary for a director to discharge his office competently. ${ }^{36}$ Another overriding consideration is that the board nominee's personality should be compatible with that of the current directors. $^{37}$ Indeed, the new board member is expected not only to work within the group's collective views of the corporate interest, but also to cooperate with other board members in reaching decisions by group consensus. ${ }^{38}$ Individuals who are quarrelsome, disagreeable, or rigid are disfavored: they fail to fit within the desired mold of "loyal independence"39 by which management is given the benefit of the doubt. ${ }^{40}$

While boards seek members who are sympathetic and compatible, director nominees, correlatively, avoid boards whose members are seen as weak or of low status. ${ }^{41}$ This mutual attraction between board members follows the welldocumented practice of individuals to select and sustain their participation in groups whose members they see as agreeable, cooperative, and like

34. See, e.g., J. Bacon \& J. Brown, supra note 25, at 30; M. Mace, Directors: Mrth and Reality 97-101 (1971).

35. See generally Buchan, Boards of Directors: Adversaries or Advisers, Cal. Mcmt. Rev.. Winter 1981, at 31, 32 (CEO's know what it is to run a company); Firstenberg \& Malkiel, Why Corporate Boards . Need Independent Directors, MGMT. REv., April 1980, at 26, 37 (need for informed board); Sethi, Cunningham \& Swanson, The Catch-22 in Reform Proposals for Restructuring Corporate Boards, MGMT. REv., Jan. 1979, at 27 (CEO's know what it is to run a company). A recent survey found that $92 \%$ of the chairmen polled disagreed with the proposition that boards should have more directors with nonbusiness backgrounds. Heidrick \& Struggles, The Changing Board 12 (1984).

36. Heidrick \& Struggles, supra note 35; see also J. Bacon \& J. Brown, supra note 25, at 30; Sturdivant \& Adler, Executive Origins: Still a Gray Flannel World, HARv. BuS. Rev., Nov.-Dec. 1976, at $125,131-32$.

37. Studies which have examined the patterns present in the new selection of replacements to the board of directors support the view that directors seek nominees of the same social class and whose experience will assure that all board members will share a common view of reality and easily reach consensus on questions presented to the board. See Koenig, Gogel \& Sonquist, Models of the Significance of Interlocking Corporate Directorates, 38 AM. J. Econ. \& Soc. 173, 176-83 (1979); see also Allen, Economic Interest Groups and the Corporate Elite Structure, 58 Soc. Sci. Q. 597, 597-607 (1978).

38. J. BACON \& J. BRown, supra note 25, at 29-33.

39. See Firstenberg \& Malkiel, supra note 35, at 26; see also M. MACE, supra note 34, at 98; J. BACON \& J. Brown, supra note 25, at 53-54.

40. See M. MACE, supra note 34 , at 97-101.

41. See generally id. at 101-06 ("motivations of directors to serve"). 
themselves. ${ }^{42}$ Importantly, these attitudes contribute to the lack of dissent so prevalent among directors. ${ }^{43}$

When an individual perceives a group, such as his colleagues on the board, as agreeable, not only is he attracted to continued association with the group, but also because of this attraction he conforms his actions to the group's views. ${ }^{44}$ Within-group conformity occurs for both positive and negative reasons. The positive reasons include personal reinforcements, enhanced self-esteem, and the comfortable atmosphere associated with agreeable social relations. ${ }^{45}$ In addition, there are negative factors that can cause conformity, including fear of rejection and group censure for individual dissent from consensus goals. ${ }^{46}$ Not only do these positive and negative factors tend to influence a group member's attitudes toward conformity, but the value or strength of the member's attraction to the group acts as a multiplier on the directional causes of conformity. ${ }^{47}$ This motivational multiplier creates an even stronger tendency for the individual to conform his personal goals, opinions, and acts to the goals, norms, and actions of highly valued groups. ${ }^{48}$ Thus, the additive tendency to conform created by positive and negative factors, when multiplied by a member's high valuation of membership within a group, produces a very powerful ingroup bias within the congenial corporate board. ${ }^{49}$

42. See, e.g., Byrne \& Griffitt, Interpersonal Attraction, 24 Ann. Rev. Psycholocy 317 (1973); Byrne, Griffit \& Stefaniak, Attraction and Similarity of Personality Characteristics, 5 J. Personality \& Soc. Psychology 82 (1967); Bryne, Interpersonal Attraction as a Function of Affliation Need and Attitude Similarity, 14 Hum. Rel. 283 (1961); Byrne, Interpersonal Attraction and Attitude Similarity, 62 J. ABN. \& Soc. Psychology 713, 713 (1961); Huston \& Levinger, Interpersonal Attraction and Relationships, 29 Ans. Rev. Psrchology 115 (1978); Marks, Interests and Group Formation, 12 Hum. Re1. 385 (1959).

43. Several popular accounts of this lack of objectivity and dissent on boards have been published. See, e.g., T. Whisler, The Rules of the Game: Inside the Corporate Boardroom (1984); M. MACE, supra note 34. One case study found that directors who discover after a few attempts that their views are not supported by their boardroom colleagues either cease raising points they believe will prove unpopular or withdraw from the board. J. BACON \& J. Brown, supra note 25 , at 42 .

44. See Endle \& Hartley, Relative Competence, Reinforcement and Conformity, 3 Eur. J. Soc. Psychology 63 (1973); Jones, Gergen \& Jones, Tactics of Ingratiation Among Leaders and Subordinates in a Status Hierarchy, 77 Psychological Monographs 1 (1963).

45. Backman \& Secord, The Effect of Perceived Liking on Interpersonal Attraction, 12 HuM. REL. 379 (1959).

46. See. e.g., Bovard, Group Structure and Perception, 46 J. Aвn. \& Soc. Psychology 398, 403 (1951).

47. See, e.g. Berkowitz, Group Norms Among Bomber Crews: Patterns of Perceived Crew Attitudes, "Actual" Crew Attitudes, and Crew Liking Related to Aircrew Effectiveness in Far Eastern Combat, 19 Sociometry 141 (1956); Berkowitz, Group Standards, Cohesiveness and Productivity, 7 Hum. Rel. 509, 519 (1954).

48. See, e.g., Dittes \& Kelley, Effects of Different Conditions of Acceptance Upon Conformity to Group Norms, 53 J. ABn. \& Soc. Psychology 100 (1956); Gerard, The Anchorage of Opinion in Face to Face Groups, 7 Hum. Rel. 313 (1954).

49. See generally G. Levinger \& J. Snoek, Atrraction in Relationship: A New Look at Interpersonal Atrraction (1972); Back, Influence Through Social Communication, 46 J. ABn. \& Soc. Psychology 9 (1951); Berkowitz \& McCaulay, Some Effects of Differences in Status Level and Stalus Stability, 14 Hum. REL. 135, 138, 146 (1961) (fear of loss of status produces conformity); Dittes, Attractiveness of Group as a Function of Self-Esteem and Acceptance by Group, 59 J. ABN. \& Soc. Psychology 77 (1959); Dittes \& Kelley, supra note 48; Kelley \& Shapiro, An Experiment on Conformity to Group Norms 
Generally, social psychologists find that a person's motivation to conform is governed by positive factors when his attraction to the group is low and by negative factors when it is high. At intermediate levels of motivation, both positive attraction and negative fear operate in the same direction and with similar forces to increase within-group conformity and out-group bias. Under high motivation conditions, however, negative fear of rejection generated by the belief that a member's decisions are being evaluated against the norms of the group to which he is attracted becomes a much stronger influence compared to positive social factors in determining conformity. ${ }^{50}$ Thus, in our particular situation, where individuals highly value their membership on a corporate board, the negative awareness that continued participation is conditional, and that their performance must be acceptable to the group, tends to dampen dissent. ${ }^{51}$

Conformity and overall cohesion within the group increase with the value each member places on membership in the group. In the case of a directorship of a public corporation, this value is extremely high. The reward which dominates the thinking of those considering an invitation to serve on a corporation's board of directors is nonmonetary. ${ }^{52}$ Individuals learning of

Where Conformity is Detrimental to Group Achievement, 19 Aм. Soc. Rev. 667, 677 (1954) (valuation of membership correlates with conformity).

50. There is a well-documented tendency for a member of a group to modify his conduct more and more as he becomes aware that his nonconforming opinions are likely to cause his rejection from the group. See Byrne \& Nelson, Attraction as a Lineal Function of Proportion of Positive Reinforcements, $1 \mathrm{~J}$. Personality \& Soc. Psychology 659 (1965); Snoek, Some Effects of Rejection lpon . Altraction to a Group. 64 J. ABn. \& Soc. Psychology 175 (1962); cf. Golightly \& Bvrne, Altilude Statements as Posilit' and Negative Reinforcements, 146 SCI. 798, 799 (1964) ("presentation of statements with attitudes similar and dissimilar to those of subject acted to change response probability"). And, of course, the more accepted one feels by a group, the more likely it is that one will conform one's beliefs to those of the group. See, e.g., Byrne \& Rhamey, Magnitude of Positive and Negative Reinforcements as a Determinate of Attraction, 2 J. Personality \& Soc. Psychology 884 (1965).

51. The psychological literature documents the well-established agenda of the impact of contingent rewards upon conformity. See generally Scott, Attitude Changes Through Reu'ard of linbal Behavior, 55 J. Abn. \& Soc. Psychology 72 (1957); Wallace, Role Reu'ard and Dissonanie Reduction. $3 \mathrm{~J}$. Personality \& Soc. Psychology 305 (1966) (role-based rewards change attitudes).

52. Many have reasoned that the compensation paid to outside directors is a reward which makes them beholden to those whom they credit with securing their nomination. Ser. e.g.. Dent. supra note 8, at 112-13; Note, The Business Judgment Rule in Derivative Suits Against Dirpors. 65 Corvil. L. Rev. 600, 620 (1980); $c$. M. EISENBERG, supra note 4. at 144.47. Median direcior compensation tor a public industrial corporation today approaches $\$ 19,000$, with an additional $\$ 2.00(1-\$ 3.000$ garncered in fees for service on board committees. The data on director compensation are quite sensitive to the size and industry classification of the company. In the most recent studv: including the 1.000 largest corporations, average outside director compensation was $\$ 17,262$ with the average industrial paying \$18,783. Heidrick \& Struggles, The Changing Board 7 (1984). In this group, the mean compensation of outside directors of companies having assets in excess of $\$ 2$ billion was $\$ 32.606$. Id. This figure is consistent with a 1981 study of 1,065 manufacturing. financial, and nonmanufacturing companies where median outside director compensation for all manufacturing companics was $\$ 25,000$ and for financial and nonmanufacturing firms median compensation was $\$ 15.800$ and \$21,085, respectively. J. Bacon, Corporate Directorship Practices: Compensation. Thie. Conference BoArd Rept. No. 815, at 1 (1981); see also Lear, Compensation for Outside Directors, Haks. Bus. Rev., Nov.-Dec. 1979, at 18. To be added to the director compensation are the fecs directors earn through membership on special committees of the board of directors which average betwern $\$ 300$ and $\$ 500$ per meeting attended. J. BACON. supra. at 8-9. An additional source of compensation are the myriad of fringe benefits that about one-half of the surveyed corporations make atailable I. their outside directors. Id. at 13. In any case, combining four or five directorships of large public 
their nomination to the board think first of the prestige, the influence, and the pleasure of associating with other successful people with whom they will share the challenges of being a director. ${ }^{53}$ Those who serve as directors look forward to serving with others they admire, with whom they wish to become better acquainted, and with whom they wish to work on important matters. ${ }^{54}$ These preferences are a manifestation of the inherent drive for affiliation and companionship which motivates people throughout life to seek self-identity in a group. Through attachment to a group, especially one of high prestige, individuals satisfy their needs to validate their self-worth, particularly by the group's feedback. ${ }^{55}$ Membership on the board of a public corporation, of

corporations would unquestionably be what Lord Boothy once referred to as "total heaven, like having a permanent hot bath." See Soft Boards, Time, Oct. 5, 1962, at 96.

But for most directors their compensation is not an important factor in their desires or decision to become a director. J. BACON \& J. Brown, supra note 25, at 56-57. This may well be due to large personal income from their primary vocation so that their declining utility for additional wealth explains why director compensation is at best a secondary consideration. This thesis is borne out by the fact that the average cash income for newly named directors in 1981 was $\$ 279,100$, with only $14 \%$ of those included in the survey reporting income less than $\$ 100,000$. Heidrick \& STruggles, Director Data 8 (1982). Only two percent of the newly elected directors derived income principally from directors' fees. Id. To be sure, the average director in a recent survey served on 3.5 boards; this figure includes the outside director's service on his own employer corporation board for which no director compensation is earned. See id. at 7. Heidrick \& Struggles, Director Data 7 (1980). Four out of five directors recently polled felt adequately compensated for their service on the board. Heidrick \& Struggles, The Changing Board 8 (1983).

53. This factor is suggested in the survey of directors' attitudes in which across all sizes of companies and industries the strongest factor identified by outside directors in joining a corporation's board is the quality of its present board. Heidrick \& Struggles, The Changing BOARD 10 (1983). The present board's quality is identified ten times more often than the compensation earned through the directorship. Id. This attitude is reflected in the informed studies by commentators on the operation of boards of directors. See, e.g., S. VANCE, Corporate LEadership Boards, Directors, and Strategy 22-59 (1983); Hannan, supra note 25, at 24. Professor Mace sums up the director's reaction to an invitation to serve with other prestigious individuals as "a little bit like being knighted." M. MACE, supra note 34 , at 88 .

54. See J. BACON \& J. Brown, supra note 25, at 56.

55. To explain the nature and meaning of social needs, biological theorists assume that human beings possess an innate "need to affiliate with other humans" and this human social need is a homogeneous dispostion or drive to affiliate. See, e.g., Martimor, Sociability: The Need for Human Social Interchange, 2 Annals Med. Psychology 807 (1979). By disposition or drive, these biological theorists mean, operationally, that human beings will expend effort, learn new skills, or endure pain to achieve social interaction with others. Social learning theorists, on the other hand, assume that social needs are acquired by conditioned reinforcement; social needs are defined operationally by social learning theorists in terms of new learning, or other techniques traditionally used by scientists.

The classic operational demonstration that motivation for social interaction operates according to the rules of primary drives is contained in Gewirtz \& Baer, The Effect of Brief Social Deprivation on Behaviors for a Social Reinforcer, 56 J. ABn. \& Soc. Psycholocy 49 (1958). Social learning theorists assume that social needs are ultimately based on the prior satisfaction and continued reinforcement of primary needs, such as hunger, thirst, sex, and safety, and the association of these primary drive satisfactions with significant other human beings, such as parents, teachers, or peers. Social learning theory assumes that conditioned secondary social needs generalize from early childhood interaction to all adult human social interactions.

Role theorists define social needs in relation to the part that other human beings play in defining the individual's self-identity and maintaining the individual's self-esteem; they assume that the need for social feedback to validate self-identity (Who am I?) and self-worth (Am I a good person?) is an important, compelling social motive. Role theorists operationally define social needs in terms of the high frequency of social interactions in everyday life, the phenomenological experience of loneliness when separated from other human beings, and the subjective satisfactions that people express based on social participation. Role theorists claim that the need for social validation and social meaning is 
course, confers the additional reward of increased status derived from the overall high prestige of the other board members.

The nonmonetary rewards for the executive officer who serves on another corporation's board are even richer than those other outsiders enjoy. This class of directors is particularly important because over seventy-five percent of all outside directors are themselves executives of other corporations, and most of these are chief executive officers. ${ }^{56}$ For the executive, a directorship on another corporation's board holds the potential of enlightening glimpses of self-analysis and comparison with his peers. The executive's need to confirm his own managerial style, policies, and practices is quite understandable in view of the limited outside experience of most chief executive officers. A significant percentage of senior executive personnel have devoted their entire professional careers to service with a single corporate employer, ${ }^{57}$ and most chief executive officers devote nearly all their professional time to their company. Membership on another corporation's board of directors, therefore, is a welcome escape from the parochialism of one's own firm.

There are, of course, other benefits derived from service on another corporation's board of directors. Through such service, executives gain broader insight into trends in finance, technology, marketing, and other fields of interest to their firm. Moreover, exposure to another firm's problems can provide advance warning of potential problem areas in their own firm, as well as insight into the strengths of contrasting management styles. Finally, association with other executives on the board provides a reassuring and

based not on expectations of material reward, but is based instead on the expectation that social relations will be inherently self-validating and worthwhile. See, e.g., Markus, The Self in Thought and Memory, in The Self in Social Psychology 102 (D. Wegner \& R. Valacher eds. 1980).

Finally, Reykowski suggests that the "traditional view of social motivation as originating from a number of social needs (or drives, or motives), . . . is much too simplistic." See Reykowski, Social Motivation, 33 AnN. Rev. Psycholocy 123 (1982). He argues that social motivation is based on a number of factors that jointly generate a tendency for people to interact socially. His list of social need factors includes motivation based on the ability of other people to satisfy basic needs such as hunger, protection, approval, aggression, or stimulation; social need factors based on the similarity of adult social relations to early parent-child interactions; and finally, social need factors of feedback to give personal meaning to the self, and validate the worth of the individual through meaningful interactions. The consensus is that human beings possess a strong need, drive, tendency, trait, or motivation to form cooperative, interdependent, interactive relations with other people; that individuals experience satisfactions in and are reinforced by social living; and people learn new skills, expend effort, and endure pain to obtain the opportunity for social relations. Since all these operational definitions support the existence of a powerful, pervasive human social need, the particular theoretical explanation is not critical to our argument.

56. In the most recent survey, $77 \%$ of the newly named directors in 1979 were either the chairman, chief executive officer, or president of their firm (55\% so identified themselves) or were an executive officer (22\%). Heidrick \& Struggles, Director Data 6 (1980); see also J. Bacon, Corporate Directorship Practices: Membership and Committees of the Board 39 (Table 9)(1973).

57. Interestingly, corporate executives appear to be losing mobility over time. In 1900 some $8.6 \%$ of corporate executives had work experience limited to one company; a 1975 study found that of 400 top executives in the 300 largest industrial corporations, $42.5 \%$ had worked only for one firm. See Sturdivant \& Adler, supra note 36, at 131. Of the surveyed directors, $75 \%$ percent served on another corporation's board of directors. Id. at 131-32. 
informal environment for candid discussions about issues at the executive's own corporation. These discussions cannot always be carried out as openly or in as relaxed an environment with that executive's own directors or management team, as they can with associates on another corporation's bo:rd. 58

A further factor driving an individual to conform his behavior to another's normative view is the personal reward the individual derives from being singled out for membership in the group and from the attention gained through such membership. The presence of this type of reward and its effect on behavior was given international attention over fifty years ago in the classic Hawthorne Studies. ${ }^{59}$ In those studies, the selection of two groups of workers caused productivity increases and favorable attitude changes independent of changes ascribable to differing working conditions or manner of compensation; some productivity increase even occurred in counterintuitive situations, such as poor illumination of the work place. The observed behavior was explained by the satisfaction each worker derived from the social interaction with fellow workers, the prestige of having been appointed to the special study group, and the pleasure of being consulted by the company's researchers. ${ }^{60}$ Importantly, the behavior modifications were in the direction favorable to the employer, the source of the reward. 131.

58. See J. Bacon \& J. Brown, supra note 25, at 57; see also Sturdivant \& Adler, supra note 36, at

59. See F. Roethlisberger \& N. Dickson, Management and the Worker (1939); H. Landsberger, Hawthorne Revisited: Management and the Worker, its Critics and Developments in Human Relations in Industry (1958); Turner, Test Room in Employee Effectiveness, 23 Am. J. Pub. Health 577 (1933).

60. In another variation, one group of workers was paid on a piece rate basis, while a second group was paid on a set wage scale; the result, under either condition, was a continuing increase in productivity for both groups. Overall, the individual operators increased their output between $40 \%$ and $62 \%$ percent over a four-year period. See Turner, supra note 59 . Not all social scientists agree with the theoretical conclusions of the Hawthorne Studies, arguing that the primary cause of the increased performance and job satisfaction at the Hawthorne plant among the experimental workers was not their selection by management and the resulting social and personal feelings of importance among the selected workers, but instead, that the financial incentives of the work were the principal influences on work morale and behavior. See Carey, The Hawthorne Studies: A Radical Criticism, 32 Aм. Soc. Rev. 403, 415-16 (1967). Most social scientists, however, support the major conclusions of the Hawthorne Studies. See, e.g., Shepard, On Alex Carey's Radical Criticism of the Hawthorme Studies, 14 ACad. Mgmt. J. 23 (1971). Shepard reexamined the Hawthorne studies and found that financial incentives were not independent causes of work morale and behavior change; rather, he found that money operates only indirectly through social and psychological factors, such as worker goals, intentions, job satisfactions, and feelings of self-worth, to change personal attitudes, feelings, and behaviors toward management and the corporation. Id. at 30-31. In further support of Shepard's conclusion that financial rewards were not the major independent factor in work morale and behavior change, Locke, Bryan \& Kendall showed, in experimental and statistical studies, that money is not an important independent variable in work morale and behavior change. See Locke, Bryan \& Kendall, Goals and Intentions as Mediators of the Effects of Monetary Incentives on Behavior, $52 \mathrm{~J}$. APPLIED Psychology 104 (1968). See generally Opsahl \& Dennette, The Role of Financial Compensation in Industrial Motivation, 66 Psychological Bull. 94 (1966). They confirmed the original conclusion of the Hawthorne Studies that social atmosphere, selection to a special group, and management attention are very important factors in work morale and behavior change, while they found that money, by itself, has no significant independent effect on worker morale and behavior change. The conclusion seems evident that financial incentives and social-psychological factors jointly determine personal attitudes. Both sets of factors are at work in the special litigation committee situation, and these sets of factors 
Research subsequent to the Hawthorne Studies has confirmed the conclusion that selection to a special group not only enhances morale but more importantly generates positive attitudes towards those who selected the subject for membership in the special group and thereafter lavished attention on the group. For example, Likert found that when managers and employees are selected to participate in committees designed to addresss "company issues," when they are made to feel influential and important, are given access to information about company goals, and are left to reach their own consensus about how to achieve these goals, there is a significant increase in their feelings of loyalty, their identification with the committee, and their gratitude toward superiors who placed them in their new role. ${ }^{61}$ In this way, the act of selection bonds the selectee to the selector.

In current corporate practice, the chief officer of the appointing company is the principal source of rewards which attach with appointment to the board. Under conventional procedures, directors are handpicked by the chief executive officer. ${ }^{62}$ Furthermore, their performance and continuation as directors are evaluated primarily by the chief executive officer. ${ }^{63}$ Because of the importance of the chief executive officer, advocates of greater director independence have urged a restructuring of the corporate organization through the use of a nominating committee ${ }^{64}$ to buffer the influence of the chief executive, as well as that of other insiders, over the selection of directors. Indeed, an increase in use of nominating committees in public

(financial incentives, special attention, and social-psychological factors) tend to influence the members of the special litigation committee in the same way-namely, in a direction more favorable to the defendant member of the board of directors and against the plaintiff in the derivative action litigation.

Blum \& Naylor concluded that

The Hawthorne Studies are significant because . . . they recognize that [morale] is the result of the specific change plus the employee's attitudes, his social situation on the job, and his previous attitudes as determined in his personal history and background. They are as timely now as when they were first conducted.

See M. Blum \& J. Naylor, Industrial Psychology: Its Theoretical and Social Foundations 326 (1967) (emphasis in original).

61. See Likert, Measuring Organizational Performance, Harv. Bus. REv., Mar.-Apr. 1958, at 41, 4648; see also Locke, Bryan \& Kendall, supra note 60. The implications of all of these studies of the Hawthorne Effect are that selection to a special committee-as in the original Hawthorne Study, or more recently in a quality circle, in the case of derivative litigation, selection to a special litigation committee-will enhance the selected member's attraction to and cohesion with the corporation and will make the selected member's attitude more positive toward management and the board members who selected him for special committee membership. Thus, the Hawthorne Effect Studies and the follow-up studies all suggest that selection of board members to serve on a special litigation committee can create positive feelings between the members of the special litigation committee and the other board members, and that these positive feelings can introduce subtle, but powerful, structural biases into the deliberations of the special litigation committee. Furthermore, these biases uniformly tend to support the defendants' case in the derivative suit litigation and to work against the plaintiff's charges.

62. M. EISENBERG, supra note 4, at 146.

63. See S. VANCE, supra note 53, at 23; M. EISENBERG, supra note 4, at 147; M. MACE, supra note 34, at 94-95.

64. This is the position of the proposal to the American Law Institute, Principles OF Corporate Governance, supra note $2, \S 3.06$, and of the reporter for that proposal, M. EISENBERG, supra note 34 , at 174-77. 
corporations is popularly seen as evidence of an informed and desirable movement toward more independent boards of directors. ${ }^{65}$

On closer analysis, however, the nominating committee usually creates only an illusion of distance between the chief executive officer and the outside nominee. In a significant percentage of nominating committees, the chief executive officer chairs the nominating committee.66 Even when the nominating committee is staffed entirely by outsiders, the chief executive officer frequently attends the committee meetings and participates in discussions. ${ }^{67}$ In other instances, the committee is chaired by the chief executive officer of another company, 68 who can be expected to be sympathetic with the company's management on the question of the "right type of person" to serve as a director. Committee practices commonly include informal discussion with the chief executive officer about potential nominees before formalizing the nomination. ${ }^{69}$ Certainly it is standard procedure for committee nominations to be submitted to the full board for final action. ${ }^{70}$ The committee can therefore be expected to make sure that its nominees are acceptable to the inside directors and, more importantly, to the chief executive officer. ${ }^{71}$ From the above it can be seen that the express or tacit approval of the chief executive officer is from the committee's perspective both a desideratum and in most cases a reality. This conclusion is further supported by works indicating that throughout the process of considering nominees there is pervasive concern that the nominee be one sensitive to the corporation's goals and acceptable to the chief executive officer, who informs the nominee of his service on the company's board. ${ }^{72}$

The process by which board members are selected, the criteria by which their candidacy and continued service are evaluated, and the motives and rewards that impel nominees and directors to serve on the board all interact to form a highly cohesive group of mutually attractive individuals. All available evidence suggests that the strength of this attraction among the directors and the value they each place upon their membership in the group are extremely high. For example, the selection criteria generate boards of

65. Nominating committees, existing in only $9.2 \%$ of the largest corporations in 1976 , were present in 79.1\% in 1982. See Heidrick \& Struggles, The Changing Board 5. (1983). Independent directors (defined as outsiders without any business or family ties to the company) constituted $84.2 \%$ of all directors serving on nominating committees in 1982. Id.

66. Based on 1982 data, three-fourths of the nominating committees of the large industrial corporations are chaired by an independent director. See Heidrick \& Struggles, The Chancing BOARD 4 (1983). The evidence is that in other instances the chief executive officer chairs the committee. See Perham, The Men Who Pick the Board, Duns Rev., Dec. 1978, at 57.

67. See Perham, supra note 66 , at 57-58.

68. Id. at 57 .

69. Id. at 58 .

70. J. Bacon, Corporate Directorship Practices: The Nominating Committee and the Directors Selection Process (1981); The Overview Committees of the Board of Directors, 35 Bus. LAW. 1335, 134 1-46 (1980); Corporate Directors Guidebook, 33 Bus. LAw. 1591, 1625 (1978). This practice is recommended in Principles of Corporate Governance, supta note $2, \S 3.06(\mathrm{~b})(1)$.

71. See Perham, supra note 66, at 57-58; see also J. BACON \& J. Brown, supra note 25, at $135,138$.

72. See supta note 34; Statement of the Business Roundtable, The Role and Composition of the Board of Directors of the Large Publicly Owned Corporation 17-21 (1978). 
directors who have highly similar backgrounds, goals, talents, and work experience: a highly cohesive, cooperative set of directors who share corporate attitudes and loyalties. In addition, the shared perception of mutual agreeableness enhances the interpersonal attraction among ingroup members and this enhanced mutual attraction creates even more conformity. The very high nonmonetary personal value that directors place on continued membership on these highly prestigious boards tend to multiply the overall cohesion of the group even more. Finally, enchanced self-esteem derived from being singled out for membership in the select group and the increased attention associated with continued group membership contribute importantly to ingroup cohesion within the boardroom and special litigation committee. Taken together, these studies all suggest that powerful psychological factors are at work within the boardroom, creating a cohesive, loyal, conforming ingroup that will support its members for positive and negative reasons, under low and high levels of motivation and group values.

\section{The Board, Self-Validation, and Bias}

Prior or ongoing interaction between individuals, called interpersonal familiarity in the psychological literature, has been repeatedly demonstrated to be a source for strong biases favoring a familiar ingroup and correlatively disfavoring a threatening or unfamilar outgroup. ${ }^{73}$ Ingroup bias is generated by the tendency to raise or reinforce one's own self-worth by magnifying differences between a person's ingroup and a threatening outgroup. In the small group or committee, ingroup bias is an analog of ethnocentrism among larger populations and nations. Both psychological research and real world experience support the conclusion that ingroup bias is a remarkably prevalent and robust phenomenon, ${ }^{74}$ one that is caused by many psychological factors, including hostility, conflict, competition, importance of the group differences, and familiarity with the environment. ${ }^{75}$ Each of these factors is present in the directors' evaluation of an "outsider's" suit against their colleague. Intergroup comparison is a common device for self-validation, and provides the source for the intergroup bias described in this section.

73. See generally H. Tajfel, Human Groups and Social Categories (1981); Differentiation Between Social Groups (H. Tajel ed. 1978); Social Identity and Intergroup Relations (H. Tajfel ed. 1982).

74. See sources cited supra note 73. An excellent review of the leading works on this subject is Brewer, In Group Bias in the Minimal Intergroup Situation: A Cognitive-Motivational Analysis, 86 Psych. Bull. 307 (1979). For an interesting application of this phenomenon in an ally's tendency to overestimate the strength of an ally and underestimate that of an enemy, see Bass \& Dunterman, Biases in the Evaluation of One's Own Group, Its Allies and Opponents, 7 Conflict Resolution 16 (1963).

75. See, e.g., M. Sherif, O. Harvey, B. White, W. Hood \& C. Sherif, Intergroup Conflict and Cooperation: The Robber's Cave Experiment (1961) [hereinafter cited as Sherif]; Allen \& Wilder, Categonization, Belief Similarity, and Intergroup Discrimination, 32 J. Personality \& Soc. Psychology 971 (1975); Dion, Cohesiveness as a Determinant of In-Group-Outgroup Bias, $28 \mathrm{~J}$. Personality \& Soc. Psychology 163 (1973); Kahn \& Ryen, Factors Influencing the Bias Towards One's Own Group, 2 INT. J. Group Tensions 33 (1972); Tajfel \& Billig, Familiarity and Categorization in Intergroup Behavior, $10 \mathrm{~J}$. Experimental Soc. Psychology 159 (1974); Worchél, Andreoli \& Folger, Intergroup Cooperation and Intergroup Attraction: The Effect of Previous Interaction and Oulcome of Combined Effort, J. EXPERIMENTAL Soc. Psychology 13 (1975). 
1. Ingroup/Intergroup Bias. The researchers involved in the classic Robbers' Cave experiment, ${ }^{76}$ for example, hypothesized that competition between ingroup and outgroup members is the major force which causes intergroup discrimination. ${ }^{77}$ They further believed that, when cooperation between two formerly distinct groups is required to complete an important common task, intergroup attractiveness occurs and over time the discriminatory practices between the two groups will disappear. ${ }^{78}$ Both predictions were generally confirmed in the Robbers' Cave experiment, but the explanations for these results were not.

In the Robbers' Cave experiment, two groups of boys at a summer camp were initially involved in a variety of camping activities, such as cooking their own meals and transporting boats to a river. These tasks were conducted in distinct groups and the resulting familiarity among the members within each group created positive ingroup cohesion. Thereafter, competitive games between the two groups were conducted, with one group winning and the other losing. Following the competition, a marked increase in hostility and generally unfavorable attitudes toward outgroup members were found. Correlatively, following the competition, a sharp increase in favorable comments about, and attitudes toward, ingroup members also appeared. The two groups were then introduced to a series of tasks that could only be accomplished through the cooperative efforts of both groups. Intergroup hostility declined and positive attitudes toward outgroup members began to appear, becoming stronger as more and more cooperative tasks were successfully completed.

Some of the evidence reported in connection with the Robbers' Cave experiment questions the study's hypothesis that competition alone produces the intergroup bias. The study's researchers observed in anecdotal remarks that shortly after the subjects were separated into groups, and prior to their competition with one another, many of the subjects jeered at the members of the other group and offered threatening challenges. ${ }^{79}$ The suggestion is that categorization itself leads to ingroup bias. This hypothesis has been borne out in subsequent research. The separation of subjects into groups, without any institutionalization of competition, has repeatedly been shown to cause intergroup bias. Indeed, regardless of whether categorization is based upon flimsy criteria such as preference between two abstract painters, ${ }^{80}$ or on purely random selection, ${ }^{81}$ systematic intergroup bias occurs. Competition

76. See Sherif, supra note 75 .

77. Id. at $96-115$.

78. Id. at 151-90.

79. Id. at 95 .

80. See Allen \& Wilder, supra note 75, at 971; Billig \& Tajfel, Social Categorization and Similarity in Intergroup Behavior, 3 EUR. J. Soc. Psycholocy 27 (1973); Brewer \& Silver, Ingroup Bias As a Function of Task Characteristics, 8 Eur. J. Soc. Psychology 393 (1978)

81. See Billig \& Tajfel, supra note 80 , at 27 (found that discrimination occurred both when subjects were told they were grouped according to preferences for painters and when informed the groupings were random; discrimination was somewhat greater when the subjects were alleged to share the same preferences, id. at 42-43); see also Kahn \& Ryen, supra note 75, at 39, 42. 
between the groups accentuates the intergroup discrimination that is generated by simple classification along benign criteria. That is, competition appears to clarify the distinctiveness of one's membership in a group so that ingroup bias is more pronounced, but competition is not a necessary condition for bias to appear. ${ }^{82}$ Clarification of group differences can also occur by emphasis on other factors, such as perception of cultural similarity among ingroup members and dissimilarity to outgroup members, ${ }^{83}$ ongoing familiarity with ingroup members and unfamiliarity with outgroup members, ${ }^{84}$ or the belief that differences exist in goals, values, or attitudes between ingroup and outgroup members. ${ }^{85}$

A particularly distressing aspect of intergroup behavior is the direction of the bias. Tajfel's studies ${ }^{86}$ presented subjects with the task of distributing monetary rewards and penalties among members of an ingroup and members of an outgroup. The choices available to the subjects were structured to enable the experimenters to determine whether subjects sought to (1) maximize the reward to ingroup members, (2) maximize the joint reward for both groups, or (3) to maximize the difference in the amount received by ingroup members and outgroup members. Tajfel's findings are startling: in confirming strong ingroup bias where categorization was based upon a very flimsy criterion, the subjects showed a strong preference for maximizing the difference between their own group and the other group, even though that strategy caused them to foresake a profit-maximizing option for their ingroup. ${ }^{87}$

The suboptimal payoff found by Tajfel has been confirmed in other studies. ${ }^{88}$ This discrimination strategy is caused by a desire to preserve owngroup/other-group distinctiveness. ${ }^{89}$ Even random classifications establish a

82. See Brewer, supra note 74 , at $311-15$.

83. The significance of the relevant studies is that the attraction of ingroup members becomes stronger with familiarity, not that the outgroup members become less attractive on an absolute scale. The relative effect, however, is that the discrimination between ingroup and outgroup members becomes more pronounced. See Anderson, Combined Effect of Interpersonal Attraction and Goal-Path Clarity on the Cohesivenes of Task Oriented Groups, 31 J. Personality \& Soc. Psychology 68 (1975); Dion, Cohesiveness as a Determinant of Ingroup-Outgroup Bias, $28 \mathrm{~J}$. Personality \& Soc. Psychology 163 (1973); Wilson, Chun \& Kayatani, Projections, Attraction, and Strategy Choices in Intergroup Competition, $2 \mathrm{~J}$. Personality \& Soc. Psychology 432 (1965).

84. See, e.g., Worchel, Andreoli \& Folger, supra note 75.

85. See, e.g., Allen \& Wilder, supra note 75; Billig \& Tajfel, supra note 80; Brewer \& Silver, supra note 80. See generally Byrne, Bond \& Diamond, Responses to Political Candidates as a Function of Attitude Similarity-Dissimilarity, 22 HUM. REL. 251 (1969) (predicting voting by attitude similarity).

86. See Billig \& Tajfel, supra note 80; Tajfel \& Billig, supra note 75; Tajfel, Billig, Bundy \& Flament, Social Categorization and Intergroup Behaviour, 1 Eur. J. Soc. Psychology 149 (1971); Vaughan, Tajfel \& Williams, Bias in Reward Allocation in an Intergroup and an Interpersonal Context, 44 Soc. Psychology Q. 37 (1981).

87. The classic article making this finding remains Tajfel, Experiments in Intergroup Discrimination, Scı. AM., Nov. 1970, at 96, 101-02. See also authorities cited supra note 86 .

88. See Allen \& Wilder, supra note 75, at 975; Brewer \& Silver, supra note 80; Turner, Social Comparison and Social Identity: Some Prospects for Intergroup Behaviour, 5 Eur. J. Soc. Psychology 5, 315$16(1975)$.

89. For an excellent description of the relationship between the drive for social identity and intergroup discrimination, see Brewer, In-Group Bias in the Minimal Intergroup Situation: A CognitiveMotivational Analysis, 86 Psych. Bull. 307, $321-23$ (1979); Turner, supra note 88, at 7-13. 
foundation for building a social identity within an ingroup, because separation from others and consequent group membership are socially significant to group members. The resulting ingroup bias is caused by a drive for self-validation, and group categorization is an important vehicle toward satisfying this social need.

As seen earlier, ${ }^{90}$ individuals associate and maintain their membership in groups that make a positive contribution toward their social identity, from which they derive emotional or value significance. A further benefit derived from membership in a group is its contribution to the members' sense of selfworth. There is a tendency for all of us to define both ourselves and others in terms of our respective locations within a system of social categories, such as a social group. The exact importance one places upon membership in a group is dependent both upon the differences perceived between one's ingroup and referrent outgroups and upon the value placed on such differences. ${ }^{91}$ Members of the ingroup derive positive support for their own self-concept and self-esteem on the basis of favorable evaluations of their own familiar ingroup compared with the unfamiliar outgroup that is seen as being different and inferior.

Studies suggest that as the attractiveness of a group and its members increases, and as the individual places greater and greater value on the rewards derived by identification with the group or continuing membership in the group, the degree of intergroup discrimination also increases. ${ }^{92}$ Heightened intergroup discrimination is caused by the individual's need to assure the primacy of his own social group and to recognize his status. The stronger the attachment to the group's values, and the more important the nonpecuniary benefits derived from membership, the stronger will be the feeling that other groups are less worthy or desirable.

The relative strength of any ingroup bias is strongly related to two factors: ${ }^{93}$ the importance of the differences an individual perceives between the groups and the familiarity of ingroup members with each other. Familiarity appears to be a dominant consideration because it has been found that the perceived differences increase and the value placed on the differences

90. See supra note 45.

91. See Tajfel, La Categorisation Sociale, in INTroduction to La Psychologie Sociale 272, 292-96 (S. Moscovici ed. 1972). On the value associated with matters of difference, there is evidence suggesting that bias occurs so long as there is a difference regardless of whether the difference is an important or an unimportant trait. See Byrne \& Nelson, The Effect of Topic Importance and Attitude Similarity-Dissimilarity on Attraction in Multi-Stranger Design, 3 Psychonomic ScI. 449 (1965); Clore \& Baldridge, The Behavior of Item Weights in Attitude-Attraction Research, $6 \mathrm{~J}$. Experimental. Soc. Psychology 177 (1970), both studies concluding that intensity of one's attraction to those expressing opinions similar to one's own may be uninfluenced by the importance of the topics being discussed. Nevertheless, the greater the importance placed on the differing characteristic the greater may be the degree of intergroup bias.

92. Allen \& Wilder, supra note 75 .

93. See Turner, Social Comparison, Similarity and Ingroup Favoritism, in Differentiation BETWEEN Social Groups 235, 250 ( $\mathrm{H}$. Tajfel ed. 1978) (factors are: importance of attribute to group, identification with ingroup, and high comparability of outgroup to ingroup); Worchel, Andreoli \& Folger, supra note 75 . 
rises in proportion to greater familiarity among ingroup members and the relative strangeness or unfamiliarity of the outgroup members. ${ }^{94}$

\section{The Corporate Context. In the context of the shareholder suit, several} forces are at work that cause the directors to identify themselves and the defendants as a discrete group and the plaintiff as a disfavored outgroup. Consequently, directors can reasonably be expected to exhibit intergroup discrimination of the type described above. The directors called upon to evaluate a derivative suit against their colleagues are not, and generally have not been, isolated from the suit's defendants. As members of the board of directors they continue to interact with the defendants, who usually remain directors or officers of the corporation. Even members of a special litigation committee who were appointed after the derivative suit was initiated are legally bound under the organic requirements for committee membership to serve as directors ${ }^{95}$ on the full board. The new special litigation committee members and the defendant directors therefore serve as colleagues on the same corporate board in addressing an array of nonderivative suit issues. Consequently, the judges and those to be judged associate on a regular basis in discharging their many tasks as corporate directors during the preliminary derivative suit skirmishes. In doing so, they share a mutual duty to serve the corporate interest, and they often adopt a common view of that corporate interest. ${ }^{96}$ Analogous studies suggest that the effect of these shared experiences is not only to bond the directors and the defendants together ${ }^{97}$

94. Allen \& Wilder, supra note 75 , at 975 , found that "[d]iscrimination (in the form of ingroup favoritism and maximum difference favoring the ingroup) was accentuated in the ingroup conditions having belief similarity and was attenuated in the ingroup conditions having dissimilar beliefs." If the outgroup is perceived as having similar attitudes and beliefs as the ingroup, however, ingroup favoritism still occurs. Id. The authors hypothesize that ingroup bias can better be overcome not by stressing the similarity of ideas and beliefs of outgroup members, but by emphasizing the differences that exist among the ingroup members. Id. at 976. Another process that can reduce ingroup bias is separating the person from his ingroup so that the presence of his ingroup colleagues does not reinforce the differences the subject sees between his group and the referent outgroup. Id.; see also Brewer \& Silver, supra note 80, at 399 (cooperative interdependence between groups reduced, but did not eliminate, ingroup preference).

95. See, e.g., Cal. Corp. Code $\$ 311$ (West Supp. 1984); Del. Code AnN. tit. 8 \$ 141 (c) (1953); N.J. Stat. AnN. \$ 14A:6-9 (West 1974); N.Y. BuS. Corp. Law \$ 712(a) (McKinney 1963 \& Supp. 1983). Regarding board committees, see generally Aurell, The Corporate Executive Committee: A Dilemma for the Nonmember Director, 17 U. FLA. L. REv. 525 (1965) (regarding liability of nonmember for act of committee); McMullen, Committees of the Board of Directors, 29 Bus. Law. 755 (1974); Note, Exccutive Committees-Creation, Procedures, and Authority, 1967 WASH. U. L. Q. 42, 53-73 (regarding permissible delegation by board).

96. See supra text accompanying note 35 . In competitive situations, when there is identification with the ingroup's common view or position, it is unusual to find that a representative of the ingroup will be persuaded to reject that view and accept that of an outgroup. See Blake \& Mouton, Loyalty of Representatives to Ingroup Positions during Intergroup Competition, 24 Sociometry 177 (1961).

97. Further evidence in the decisions of special litigation committees is that committees have proffered unequivocal recommendations to pursue suits against only those who were not the committee members' colleagues, but were instead subordinate corporate officers and personnel. See In re Continental Ill. Sec. Litig., 732 F.2d 1302 (7th Cir. 1984); Chase Manhattan Bank Nat'l Ass'n v. Higgerson, N.Y.L.J., Feb. 6, 1985, at 1, col. 1 (Index No. 17864/84, Oct. 11, 1984); Tharp, Bank of America Files 2 Lawsuits, Fires 5 Workers, Wall St. J., Mar. 4, 1985, at 5, col. 1; Zonana, Banktmerica 's Seafirst to Pursue Claims Against Former Head and Auditing Firm. Wall St. J., Aug. 21, 1984, at 4, col. 2. 
but also to form a basis upon which the directors can be expected to give greater weight to the defendant's values, attitudes, and perceptions than to those of outgroup members like the plaintiff. ${ }^{98}$ Indeed, the greater the interaction between the defendants and directors, in terms of frequency and degree of task complexity, the stronger the favoritism the directors can be expected to express toward the defendants. ${ }^{99}$ While this favoritism does not necessarily cause the outgroup member (the plaintiff) to be held at a lower level of esteem, in an absolute sense, than when there was no interaction between ingroup members, on a relative scale a greater regard results for ingroup members than for outgroup members. ${ }^{100}$

More is involved in the dynamics of intergroup discrimination in the demand or special litigation committee context than the seemingly simple categorization of the nondefendant directors as "directors," a category which also includes the defendants. As seen earlier, ${ }^{101}$ individuals place great value on their selection to and membership on a corporation's board: They are attracted to their colleagues and value greatly the associations they reap from the directorship. The relative attractiveness and rewards of board membership to the nondefendant director are important considerations in the director's ability to be an impartial arbitrator of a colleague's behavior.

A variety of psychological factors contributes to ingroup bias. Not only does each of these biasing factors, such as continued association, competition from without, complexity of shared tasks, and mutual attraction contribute its individual influence to the overall strength of ingroup biasing, but when several complementary psychological factors occur together within the same person, they tend to exert extra psychological force by their coexistence. This enhanced effect is commonly referred to as synergism or wholeness; it means that the total influence of a coherent system of psychological factors is more than the simple sum of its components. Rather, when several compatible psychological factors come together as a whole system, they jointly enhance total ingroup bias, so the effect is greater than we would expect on the basis of a simple additive model alone. This synergetic whole system has been observed frequently in the psychological literature. It is as if a coherent attitudinal system takes on a life of its own, and the wholeness enhances the influence of each individual factor. As a coherent, congruent system within the single person, this synergism creates compelling psychological forces toward ingroup biases within the board or the special litigation committee.

98. See supra text and authorities accompanying notes 83-88.

99. See Brockner \& Swap, Effects of Repeated Exposure and Attitudinal Similarity on Self-Disclosure and Interpersonal Attraction, 33 J. Personality \& Soc. Psychology 531 (1975). The Brockner \& Swap study found increasingly positive ratings of ingroup members as a function of familiarity with group members gained through their interaction over discrete time intervals, but did not measure the effect of this increasing personal attraction or its potential discriminatory effect on outgroup members. These findings are presented infra note 100 .

100. See, e.g., Worchel, Andreoli \& Folger, supra note 75, at 131 (finding that prior cooperative personal relations produced strong positive bias in favor of ingroup members and strong negative bias against outgroup members); $f$. Tajfel \& Billig, supra note 75.

101. See supra text at notes $52-58$. 
3. Cultural Similarity. Of course, both the rewards of group membership and the attractiveness of being in a group are accentuated by the degree of cultural and intellectual similarity among the group's members. Authorities agree that people prefer to associate with others of similar cultural background. ${ }^{102}$ In fact, cultural, personal, ethnic, and even linguistic similarities are factors that increase the members' mutual attraction for each other. ${ }^{103}$ The heightened mutual attraction among a group's members causes each member to have a stronger drive toward ethnocentrism and intergroup bias. ${ }^{104}$ Correlatively, cultural dissimilarity of an outgroup exacerbates the intergroup discrimination. The relationship among attraction, similarity, and ingroup bias is an important one in the American boardroom.

Even though there is a perceived "greening" of today's boardroom in the era of the independent director, the boards of American corporations continue to be distinguished by their homogeneity. ${ }^{105}$ Moreover, there is a

102. This phenomenon is apparent in children and increases with the subject's age. See Vaughn, Social Categorization and Intergroup Behavior in Children in Differentiation Between Social Groups 339 (H. Tajfel ed. 1978); D. Miller, Children and Race (1975); Tajfel, Nemeth, Jahoda, Campbell \& Johnson, The Development of Children's Preference for Their Own Country, 5 INT'L J. Psycholocy 245 (1970); Vaughan, Social Categorization and Intergroup Behavior in Children, in Differentiation BetweEN Social Groups 339, 339-60 (H. Tajfel ed. 1978).

103. See, e.g., Bourhis, Giles \& Tajfel, Language as a Determinant of Welsh Identity, 3 Eur. J. Soc. Psychology 447 (1973); Brock, Communicator Recipient Similarity and Decision Change, 1 J. Personality \& Soc. Psychology 650 (1965); Izard, Personality Similarity, Postive Affect, and Interpersonal Attraction, $6 \mathrm{~J}$. ABN. \& Soc. Psychology 485 (1960); Tajfel, Sheikh \& Gardner, Content of Stereotypes and the Inference of Similarity Between Members of Stereotyped Groups, 22 Acta Psychologica 191 (1964). Other factors also have been identified which contribute to the strength of ingroup bias because they relate directly to the attractiveness of the group and the rewards conferred by membership and by identification with the group. One such factor is the success of the group, with greater ingroup bias being detected when the group is successful than when it fails. See Kahn \& Ryen, supra note 75, at 42-43.

104. A sound review of the leading works appears in Rosenblatt, Origins and Effects of Group Ethnocentrism and Nationalism, $8 \mathrm{~J}$. CoNfLICT RESOLUTION 131 (1964). A particularly interesting case study of discrimination based on cultural differences is presented in Branthwaite \& Jones, Fairness and Discrimination: English Versus Welsh, 5 EUR. J. Soc. Psycholocy 323 (1975). See also Festinger, $A$ Theory of Social Comparison Processes, in Small Groups: Studies in Social Interaction 146 (A. Hare, E. Borgatta \& R. Bales eds. rev. ed. 1965).

105. In the context of the derivative suit, homogeneity of the American boardroom is important primarily because of the impact that cultural similarity has on director cohesion and ultimately ingroup bias. In this respect, it is important to recognize three criteria of a cohesive social class: (1) ingroup interaction to the exclusion of outgroup interactions; (2) common lifestyles different from other groups; and (3) an awareness of the class as a separate entity. See R. Brown, Social Psychology 114 (1965). Each of these characteristics has been amply documented in the sociological studies of the boardroom. The most popular of these studies is G. Dомноғ;, Wно Rules AMERICA? (1967). Domhoff concluded that the cohesion between members of the American upper class is based on cultural similarity. See id. at 38-62; see also G. DomHoff, THE Higher Circles (1970). Others have also reported on the cultural similarities of the American boardroom. See generally G. Domhoff, The Bohemian Grove and Other Retreats: A Study of Ruling Class Cohesiveness (1974); T. Dye, Who's Running america? (1976); F. Hunter, Top Leadership, U.S.A. (1959); L. Kavaler, The Private World of High Society (1960); Dye \& Pickering, Governmental and Corporate Elites: Convergence and Differentiations, 36 J. PoLrTics 900 (1974); Hacker, The Elected and the Anointed: Two American Elites, 55 Am. PoL. ScI. Rev. 539 (1961); Miller, American Historians and the Business Elite, $9 \mathrm{~J}$. Econ. History 184 (1949). Elitism is not uniform across industry classifications, however, and even varies among distinct subclassifications within the same general industry category. See Weston, Social Characteristics and Recruitment of American Mass Media Directors, 55 JourNaLISM Q. 62 (1978) (finding broadcast media more elite than corporate leaders generally or the print media specifically). There are indications, however, that within emerging industrial categories, 
great cultural gulf between the directors and their "adversary" in the derivative suit. ${ }^{106}$

The most open boardroom similarities are that ninety-three percent of directors are college educated, ${ }^{107}$ white males. ${ }^{108}$ With a median age of $54,{ }^{109}$ they are predominantly Protestant and Republican. ${ }^{10}$ In one older study, an amazing fifty-six percent of all directors were found to be graduates of only fifteen elite colleges; by comparison, only fourteen percent of the surveyed directors were graduates of the top ten state universities. ${ }^{111}$

The income level ${ }^{112}$ of public directors assures a lifestyle and range of vocational interests that comfortably align them with the lifestyle of their colleagues. To be sure, not all directors frequent Rodeo Drive, but they remain a long way from Pat Nixon's cloth coat and, more generally, the middle class. In short, directors have the financial means to share similar social interests.

Far more important than socioeconomic similarity in attracting group members and in maintaining ingroup cohesion is the fact that over seventyfive percent of corporate directors are themselves captains of industry or close advisors to those who are. ${ }^{113}$ Their common vocational interest fosters a natural camaraderie between the outside directors and managers. They approach their task as directors with a deep personal understanding of, and respect for, the burdens of management. One of the rewards, and indeed the paramount one, sought by serving on another corporation's board is sharing

particularly those devoted to consumer services or high technology, the managerial ranks are more heterogeneous. See The New Corporate Elite, Bus. WK., Jan. 21, 1985, at 62.

106. That the prosecutors of the derivative suit will be perceived as different from the directors and defendants is suggested by the cultural background of the plaintiff's attorney. It is the plaintiff's attorney who is important in this comparison because the plaintiff has an inactive role in the derivative suit. Studies have repeatedly shown that the representatives of noncorporate America, and more particularly attorneys involved in contingency fee litigation such as the derivative suit, have an ethnic and educational background quite different from that of the legal advisors and directors for public corporations. See J. Heinz \& E. Laumann, Chicago Lawyers: The Social Structure of the Bar (1982); Cappell \& Halliday, Professional Projects of Elite Chicago Lawyers, 1950-1974, 1983 AM. B. FOUND. RESEARCH J. 291 (1983).

107. See Heidrick \& Struggles, Director Data 8 (1982). This statistic may not impress many as significant until it is recognized that the directors would have completed college at at time when less than five percent of the population was graduating from college. See Weston, supra note 105, at 66 .

108. See Heidrick \& Struggles, The Changing Board 4 (1983).

109. See Heidrick \& Struggles, Director Data 7 (1982) (median age of industrial directors).

110. Whereas approximately $58 \%$ of the United States population is Protestant, $73 \%$ of the directors of public corporations are Protestant; and $18 \%$ of the directors are Roman Catholic in a nationwide population that is. 30\% Catholic. See Heidrick \& Struggles, Director Data 8 (1980).

111. See Vance, Higher Education for the Executive Elite, Cal. MGmT. Rev., Spring 1966, at 2-22. More recently, it was found that the most popular four colleges attended by corporate executives serving on the boards of American corporations in 1900 remained the top four schools for the 1975 boards of directors. See Sturdivant \& Adler, supra note 36, at 130-31.

112. One study has placed the average income of the outside directors at $\$ 279,100$, with less than $14 \%$ of all directors reporting income less than $\$ 100,000$. See Heidrick \& Struggles, Director Data 8 (1982).

113. See Heidrick \& Struggles, Director Data 6 (1980); see also J. Bacon, supra note 56, at 29 (Tables 5 \& 6)(1973); of. Sturdivant \& Adler, supra note 36, at 127, 131 (reports that $74 \%$ of the 444 executives studied served on the board of another corporation). 
insights gained from service on the board as well as from members' personal experiences. ${ }^{114}$ In this way, each director seeks to gain from the others: It would be unnatural for the outside directors to be skeptical or suspicious of their colleagues and fellow managers.

Finally, it deserves mention that a strong pattern has been repeatedly observed in studies of the background of new replacements to vacancies on boards created by a member's departure. Continuing directors replicate their cultural backgrounds and social ties by selecting new members who are like themselves. ${ }^{115}$ Their selections tend to be individuals with whom a sitting director has shared experience, either in a business setting, community activity, or social organization. In sum, the boards of today's public corporation remain as they have been for years, a culturally cohesive group. The movement toward board independence heralded by commentators, while addressing concerns that the directors are frequently financially dependent upon the corporation or its management, has not introduced cultural pluralism to the American boardroom.

Our goal has been to describe the social and psychological processes within the boardroom that generate systematic biases into the directors' assessment of their colleague, with special attention to derivative suit procedures. As seen above, ingroup bias is detected when groups are separated according to even the most benign criteria. ${ }^{116}$ Moreover, the direction of such bias is suboptimal; it follows a scheme that avoids maximum enrichment of the ingroup. Instead, the bias favors greater intergroup difference. The strength of intergroup bias is increased significantly by those very factors that characterize service on a corporation's board, such as highly valued personal nonpecuniary rewards derived from the director's selection and service, continuing personal associations in undertaking and completing corporate tasks, and common cultural characteristics that are markedly different from those of the plaintiff or his representatives.

We are careful to observe that the studies examined do not conclude that directors are biased or that their well-documented proclivity to shield collegues from derivative suits is the product of such bias. Indeed, this precise question remains unexplored in the social psychology literature. Also, even given our description of the many biasing agents, these studies do not tell us whether natural psychological bias is so strong that it cannot be overcome by the advocacy of plaintiff's counsel or by the directors' knowledge that their evaluations will be reviewed by a court. Minimally, however, these factors strongly suggest there is bias in the boardroom favoring colleagues and disfavoring the derivative suit plaintiff. Furthermore, the preceding description offers no support for current assumptions that "outside" directors

114. See supra text accompanying note 56 .

115. See Allen, supra note 37, at 607; Koenig, Gogel \& Sonquist, supra note 37 , at 178-79.

116. It is also distressing that the individual's tendency toward ingroup favoritism is stronger when making a judgment regarding fellow members of the ingroup than when acting individually. See Dustin \& Davis, Evaluative Bias in Group and Individual Competition, $80 \mathrm{~J}$. Soc. Psychology 103 (1970). 
can be expected to act impartially, absent family or financial relationship with the defendants or a direct involvement in the underlying transaction.

III

\section{Legal Norms and Psychological Bias}

The threat that bias will corrupt the directors' judgment of their colleague's behavior or the corporate interest served by a derivative suit's continuance has been recognized frequently by the courts in recent years, ${ }^{117}$ causing closer scrutiny for bias of the directors' recommendation. ${ }^{118}$ The courts' descriptions of the causes of director bias, as well as those offered by commentators, 119 fail to be as complete as the explanation offered in the previous sections, causing both commentators and the courts to propound inadequate procedures to counteract the effects of director bias. In this section, we critique both the structural suggestions offered in the proposal to the American Law Institute ${ }^{120}$ and the ad hoc approach of courts in responding to potential of director bias.

\section{A. Directors and the Dilemma}

To the corporate lawyer, it is elementary knowledge that directors are seldom exposed to liability for business misjudgments and that courts only rarely, and with great reluctance, intrude into directors' business decisions. ${ }^{121}$ This "hands-off" attitude has its foundation in the view that shareholders have greater aversion to risk than do managers. ${ }^{122}$ The manager's role

117. See, e.g., Hasan v. CleveTrust Realty Investors, 729 F.2d 372, 379 (6th Cir. 1984); Joy v. North, 692 F.2d 880, 888 (2d Cir. 1982), cert. denied, 460 U.S. 1051 (1983); Lewis v. Curtis, 671 F.2d 779 (3d Cir. 1982); Stein v. Bailey, 531 F. Supp. 684, 693 (S.D.N.Y. 1982); Mills v. Esmark, Inc., 544 F. Supp. $1275,1283-85$ nn.4, 6 \& 9 (N.D. Ill. 1982). In an important decision, the Delaware Supreme Court described the director's empathy for the defendants as a "there but for the grace of God go I" attitude. Zapata Corp. v. Maldonado, 430 A.2d 779, 787 (Del. 1981).

118. See infra notes 168-91 and accompanying text.

119. See Block \& Prussin, The Business Judgment Rule and Shareholder Derivative Actions: Viva Zapata?, 37 Bus. LAw. 27, 65-70 (1981); Coffee \& Schwartz, The Survival of the Derivative Suit: An Evaluation and a Proposal for Legislative Reform, 81 Colum. L. REv. 261 (1981); Dent, supra note 8; Steinberg, Maldonado in Delaware: Special Litigation Committees-An Unsafe Haven, 9 SEc. REc. L.J. 381, 385-87 (1982); Comment, A Procedural Trealment of Derivative Suit Dismissals by Minority Directors, 69 Calif. L. Rev. 885 (1981); Note, The Business Judgment Rule in Derivative Suits Against Directors, 65 Cornell L. Rev. 600 (1980); Comment, Zapata Corp. v. Maldonado: Restricting the Power of Special Litigation Committees to Terminate Derivative Suits, 68 VA. L. Rev. 1197, 1206 (1982).

120. American Law Institute, Principles of Corporate Governance: Analysis and Recommendations $\$ \S 7.07-7.12$ (Discussion Draft No. 1,1985 ) [hereinafter cited as Corporate GovernanCE].

121. See generally Arsht, Business Judgment Rule Revisited, 8 HofsTrA L. REv. 93, 130-33 (1979); Arsht \& Hinsey, Codified Standards_Safe Harbor but Chartered Channel: A Response, 35 Bus. LAw. 947, 958 (1980); Bishop, Sitting Ducks and Decoy Ducks: New Trends in the Indemnification of Corporate Directors and Officers, 77 YALE L.J. 1078, 1095-1101 (1968); Veasey \& Manning, Codified Standard-Safe Harbor or Unchartered Reef? An Analysis of the Model Act Standard of Care Compared with Delaware Law, 35 Bus. LAW. 919, 930-40 (1980).

122. Consider that shareholders may diversify their investments and therefore reduce their risk, while managers are expected to devote their full energies to a firm so that their futures are more heavily dependent upon a single firm's fortunes. See Klein, The Modern Business Organization: Bargaining Under Constraints, 91 YALE L.J. 1521, 1559-60 (1982). Professor Klein sees the inability of 
includes risk seeking, mindful that the greater returns lie with opportunities having the greater risk. The linkage between risk and return offers the most compelling justification for judicial deference to managerial decisions. ${ }^{123}$ It is argued that an overly intrusive judicial approach would discourage legitimate and necessary entrepreneurial risk taking. Judicial intrusion creates a fear that decisions resulting in corporate losses will subject corporate managers to liability. This fear is heightened by the volatility of the business environment and the frequent need for corporate decisions to be made on the basis of incomplete or imperfect information. ${ }^{124}$ Moreover, even though theoretically the circumstances under which a decision is rendered should be considered in judging whether the directors were negligent, the crispness with which a trier of fact will understand those circumstances as they then existed, as contrasted with how they are reconstructed with the benefit of hindsight, interjects a pernicious dimension into any activism on the court's part. Further supporting this deference to the directors' business judgments is the view that directors are, at least in the normative view, selected because of their experience in, knowledge of, or sensitivity to production, finance, or the marketplace. These are not entry level qualifications to the judiciary.

The commercial considerations which justify the courts' overwhelming deference to the directors' business decisions are not present, however, when a special litigation committee urges dismissal or when the board of directors rejects a demand for suit. In these situations, the courts need not be chastened by a fear that their disturbance of the directors' recommendation to dismiss the suit will either expose the directors to draconian liability or involve the court in an unfamiliar inquiry. Following a court's rejection of the directors' recommendation, the causal link between the directors' judgment and harm resulting from their recommendation is broken, so that a court's disagreement with a committee's recommendation does not carry the corollary effect of holding those directors liable. And the decision whether to continue a derivative suit is not, strictly speaking, one uniquely within the directors' natural business aptitude and beyond the abilities of the court.

managers to diversify their risks as a reason why they prefer corporate structures which enable managers to control the firm without holding a significant amount of the firm's stock. Id.; see also Anderson, Conflicts of Interest: Efficiency, Fairness and Corporate Structure, 25 U.C.L.A. L. REv. 738, 775-76 (1978); Fama, Agency Problems and the Theory of the Firm, 88 J. Pol. Econ. 288, 295 (1980). See generally Werner, Management, Stock Market and Corporate Reform: Berle and Means Reconsidered, 77 Colum. L. REV. 388 (1977).

123. For an interesting exchange on the effect that liability for violations of the fiduciary's duty of care will have on socially desirable entrepreneurial activity, see Scott, Corporation Law and the American Law Institute Corporate Governance Project, 35 Stan. L. Rev.927 (1983); Cox, Compensation, Deterrence, and the Market as Boundaries for Derivative Suit Procedures, 52 GEo. WASH. L. REv. 745, 758-63 (1984), and Coffee, Litigation and Corporate Governance: An Essay on Steering Between Scylla and Charybdis, 52 Geo. Wash. L. Rev. 789 (1984).

124. Feinberg \& Levenstein, How Do You Know When to Rely on Your Intuition, Wall St. J., June 21 , 1982 , at 16, col. 3 . For a case in which directors were protected when called upon to make a decision on incomplete information, see Bennett v. Propp, 41 Del. Ch. 14, 22-25, 187 A.2d 405, 409-10 (1962). 
The absence of commercial necessity for deference to the directors' judgment, combined with psychological attachment among the directors, makes a compelling case for heightened judicial scrutiny of the directors and their recommendation concerning the continuation of a derivative suit. ${ }^{125}$ One far-reaching approach to solving the question of how best to provide this scrutiny is the provocative one recently upheld by the Supreme Court in Daily Income Fund, Inc. v. Fox, ${ }^{126}$ in construing Section $36(\mathrm{~b})^{127}$ of the Investment Company Act of 1940. Section 36(b), added to the Act in 1970, 128 imposes a fiduciary duty upon investment advisors of registered investment companies with respect to their management fees and provides that either the SEC or any fund security holder may bring an action on behalf of the company.

The question in Fox was whether a shareholder bringing an action under section 36(b) is required by Federal Rule of Civil Procedure 23.1 first to make a demand upon the board of directors. ${ }^{129}$ While other courts had held that a demand was required, they equivocated about whether the directors' rejection of the demand barred the suit. ${ }^{30}$ The Supreme Court found in section

125. See, e.g., Joy v. North, 692 F.2d 880, 885-86, 888-89 (2d Cir. 1982), cert. denied, 460 U.S. 1051 (1983); Brudney, The Independent Director-Heavenly City or Potemkin Village?, 95 Harv. L. Rev. 597, 630-31 (1982); Coffee \& Schwartz, supra note 119, at 280-83.

126. 464 U.S. 523 (1984).

127. 15 U.S.C. $\$ \S 80 \mathrm{a}-35$ (b) (1982).

30.

128. Investment Company Amendment Act of 1970, Pub. L. No. 91-547, 84 Stat. 1413, 1428

129. See Fed. R. Crv. P. 23.1.

130. See Weiss v. Temporary Inv. Fund, Inc., 692 F.2d 928, 942 (3d Cir. 1982), vacated, $104 \mathrm{~S}$. Ct. 989 (1984) (remand in light of Fox); Grossman v. Johnson, 674 F.2d 115, 120 (1st Cir.), cert. denied, 459 U.S. 838 (1982). The uncertainty on this question was introduced by the Supreme Court's dicta in Burks v. Lasker, 441 U.S. 471 (1979), which proferred a two-step test federal courts must follow in evaluating a special litigation committee's recommendation to dismiss a cause of action based on federal statute: First, the court must decide under applicable state law what the effect, if any, a committee's recommendation has upon continuance of the derivative suit; and, second, it must determine whether a dismissal would be inconsistent with the policy embodied in the federal cause of action. Id. at 480. As an example of inconsistency between a committee's recommendation and federal statute, the Court referenced section $36(\mathrm{~b})$. Id. at 484 . Pre-Burks cases, however, found no inconsistency and required the plaintiff to comply with Rule 23.1. E.g., Untermeyer v. Fidelity Daily Income Trust, 79 F.R.D. 36, 44-46 (D. Mass), vacated on other grounds, 580 F.2d 22 (1st Cir. 1978); Boyco v. The Reserve Fund, Inc., 68 F.R.D. 692, 696-97 (S.D.N.Y. 1975).

The Weiss court believed that, because Congress required $40 \%$ of the investment company's directors to be independent, Congress necessarily expected that this independent body would take whatever steps were necessary to protect the fund from excessive management fees, including suing to recapture such sums. See $692 \mathrm{~F} .2 \mathrm{~d}$ at $942-43$. This analysis gives too much weight to the voice of a minority group of directors (even though a sizable minority) and insufficient weight to several conflicting provisions contained in the 1970 Amendments. First, section 36(b) empowers suit only by the SEC or a shareholder; the corporation is not expressly empowered to sue. This omission, while perhaps to be filled by implication, nevertheless is consistent with the view expressed in Fox that Congress intended to preclude substantive involvement by the directors. Daily Income Fund v. Fox, 464 U.S. 523 (1984). Second, section 36(b)(2) implores the courts to give such weight as they believe appropriate to board decisions that approve compensation. This provision appears to reject Weiss's argument regarding the role of independent directors in support of the position taken in Fox. Congress, in seeking to curb excessive management fees, enacted both a requirement for independent directors and an express cause of action for excessive fees. It therefore appears Congress must have envisioned that the independent directors would at times be ineffective, so that some auxiliary means to protect the shareholders would be necessary. Both safeguards were believed necessary. Third, section 36(b)(3) limits recovery to the excessive fees paid within one year of when the action was instituted, so that requiring a demand could have the effect of precluding full 
36(b)'s legislative history that Congress intended to remove the directors' input completely. The special studies prepared for the SEC and congressional reports accompanying the 1970 amendments catalogued the impotence of the mutual fund directors as well as of the courts in curbing the size of management fees. ${ }^{131}$ Without equivocation, Congress blamed the directors' impotence on the incestuous relationship between the investment company and its advisor. ${ }^{132}$ The Court in Fox, reasoning that Congress could not have intended to subject the private enforcement of the fiduciary standard it imposed in 1970 to the structural biases captured in the enactment's legislative history, concluded that the action authorized under section $36(\mathrm{~b})$ is not a derivative action so that Rule 23.1 is therefore inapplicable. ${ }^{133}$

The most dramatic aspect of Fox is not its rejection of the necessity of making a demand but its conclusion that the suit under section 36(b) was not a corporate cause of action. The holding substantially removes a court's procedural flexibility to deal with the twin concerns of improvidently initiated actions against corporate officials and abusive practices that arise in connection with settlements and voluntary dismissals of derivative suits which Rule 23.1's procedures were intended to address. These effects were achieved by the Fox Court focusing exclusively upon the potential tyranny of the board of directors in responding to a suit. In doing so, the Fox Court gave insufficient attention to the potentially corrupting incentives that pervade representative suit litigation such as the derivative suit. ${ }^{134}$ The derivative suit plaintiff is self-selecting; without appointment or election, he purports to represent the corporation's interest. ${ }^{135}$ Rarely do derivative suit plaintiffs

recovery. See Fox v. Reich \& Tang, Inc., 692 F.2d 250, 261-62 (2d Cir. 1982), affd sub nom. Daily Income Fund v. Fox, 464 U.S. 523 (1984). Weiss's response to this consideration was an expressed hope that demand be made and responded to expeditiously. $692 \mathrm{~F} .2 \mathrm{~d}$ at 938 .

131. See generally Wharton School of Finance \& Commerce, A Study of Mutual Funds, H.R. Rep. No. 2274, 87th Cong., 2d Sess. (1962); SEC, Public Policy Implications of Investment Company Growth, H.R. REP. No. 89-2337 (1966). This history is examined in Daily Income Fund v. Fox, 464 U.S. at 536-41.

132. See Daily Income Fund v. Fox, 464 U.S. at 536 (investment company is typically created and managed by preexisting external organization known as investment advisor).

133. Id. at 842 .

134. See Coffee, The Unfaithful Champion: The Plaintiff As Monitor in Shareholder Litigation, LAw \& Contemp. Probs., Summer 1985, at 5; Conard, Winnowing Derivative Suits Through Attormeys Fees, Law \& Contemp. Probs., Winter 1984, at 269; Coffee, Rescuing the Privale Attorney General: Why the Model of the Lawyer As Bounty Hunter Is Not Working, 42 MD. L. Rev. 215 (1983); Note, Class Action Treatment of Shareholders' Suits under Section 36(b) of the Investment Company Act, 83 Colum. L. Rev. 2039, 2063-67 (1983). For the view that courts may overcome the problems created by Daily Income by continuing to consider a recommendation of a special litigation committee, see Smith, Daily Income Fund, Inc. v. Fox-No Demand Requirement for Section 36(b) Advisory Suits Gives Rise to Potential Abuses, 12 SEc. REG. L. REv. 299 (1985).

135. An earlier requirement that the plaintiff seek stockholder approval before he initiated the suit, see, e.g., Hawes v. Oakland, 104 U.S. 450, 461 (1881), is now regarded as inefficient and inexpedient. See, e.g., Interstate Refineries, Inc. v. Barry, 7 F.2d 548, $551-52$ (8th Cir. 1925); Bell v. Arnold, 175 Colo. 277, 282, 487 P.2d 545, 547-48 (1971); Campbell v. Loew's, Inc., 36 Del. Ch. 533 , 536-37, 134 A.2d 565, 567 (1957); Tevis v. Hammersmith, 31 Ind. App. 281, 287-88, 66 N.E. 79, 81 82, affd, 161 Ind. 74, 67 N.E. 672 (1903). But cf. S. Solomont \& Sons Trust, Inc. v. New England Theatres Operating Corp., 326 Mass. 99, 114, 93 N.E.2d 241 , 249 (1950) (majority of independent stockholders can ratify actions of directors); Claman v. Robertson, 164 Ohio St. 61, 73, 128 N.E.2d $429,436(1955)$ 
have a significant ownership interest in the corporation. The plaintiff, therefore, is driven neither by a sense of fiduciary duty to his fellow stockholders nor by the expectation that his shares will appreciate in value because of the suit. Indeed, throughout the derivative suit the plaintiff has a minimal role. ${ }^{136}$ Rather, the contingent fee payable to plaintiff's counsel, which is not totally dependent upon the size (or even the existence) of the recovery, ${ }^{137}$ has a pivotal role in assuring the frequency of derivative suit litigation. ${ }^{138}$ This is not to suggest that plaintiff's counsel can be insensitive to the strengths of the suit's allegations against the defendants. His professional reputation and continued effectiveness are important, but not completely adequate, safeguards against abusive practices by the plaintiffs' bar. Nevertheless, it would be an overstatement to suggest that either the plaintiffs or their attorneys are unwavering guardians of the corporate interest in their evaluation of the suit's worth and impact.

An improvidently prosecuted derivative suit may harm the stockholders' interest far more than it harms the defendants of that action. For example, in the event of an unsuccessful derivative suit, all the defendants' litigation expenses are borne by the corporation, as are all the indirect costs of the suit such as injury to morale, loss of reputation, or deflection of employee time. Even though insurance frequently mitigates the amount of these losses, the concern nevertheless is that an unsuccessful, ill-advised derivative suit visits costs upon the corporation's stockholders. Furthermore, unlike its relative the class action, a derivative suit inextricably weds all the shareholders, through their stock ownership, to the costs and benefits of the suit. Only through divesting their shares may they avoid the adverse affects of a poorly advised derivative suit, whereas in a class action class members may protect

136. The plaintiff's deficiencies, due to health, experience, or education, in understanding the nuances of the litigation do not disqualify the derivative suit plaintiff so long as the court believes that vigorous representation is provided by the suit's counsel. Fradkin v. Ernst, 571 F. Supp. 829 (N.D. Ohio 1983); Ross v. A.H. Robins Co., [1982-1983 Transfer Binder] Fed. SEC. L. REP. (CCH) I 99,052 (S.D.N.Y. 1982); Fischer v. International Tel. \& Tel. Corp., 72 F.R.D. 170 (E.D.N.Y. 1976). However, this is not to reject the requirement of a plaintiff. Even when settlement has been approved, the derivative suit must be dismissed if the derivative suit plaintiff is no longer living. Paolozzi v. Barber, 260 A.2d 176, 179 (Del. Ch. 1969).

137. Utilization of the "lodestar figure" upon which a contingency bonus is calculated by the court, by recognizing not only the entrepreneurial risks of the litigation but also the unusual talent and challenges present in the suit, allows courts great flexibility in approving the award of fees. See e.g., City of Detroit v. Grinnell Corp., 495 F.2d 448, 470-72 (2d Cir. 1974); Lindy Bros. Builders v. American Radiator \& Standard Sanitary Corp., 487 F.2d 161, 166-70 (3d Cir. 1973). It is the court's inability to measure fully the suit's potential, however, which introduces the pernicious quality into fee awards. With the recognition that suits can serve the corporate interest even though they do not produce sizable monetary awards, see Mills v. Electric Auto-Lite Co., 396 U.S. 375, 395-97 (1970), it is problematic whether any large award of counsel fees, from the corporation's fisc or from the amount recovered in the settlement, was the product of a suit with merit or an extortionate settlement. See generally Coffee, supra note 134; Leubsdorf, The Contingency Factor in Attorney Fee Awards, 90 YaLE L.J. 473 (1981).

138. Hornstein, Legal Therapeutics: The "Salvage" Factor In Counsel Fee Awards, 69 HARv. L. REv. 658,663 (1956), analogized to the law of salvage in admiralty cases in explaining the necessity for fee awards in derivative suit litigation: "There must always be a flavor of generosity in the awards to success in order that an appetite for effort may be stimulated." Id. (quoting from In re Osofsky, 50 F.2d 925, 927 (S.D.N.Y. 1931)). 
themselves from the detrimental effects of a misguided or wasteful prosecution by opting out of the plaintiff class. ${ }^{139}$ This distinction invites greater receptiveness to a pretrial screening of the derivative suit's impact than to prescreening the class action.

Thus, neither the derivative suit plaintiff nor his representative can always be expected to protect the corporation from harmful effects of a suit. Moreover, in comparing the plaintiffs and defendants, the plaintiffs have more circumscribed access to the facts surrounding the suit's allegations and the suit's impact upon the conduct of the corporation's business than do the defendants. Concerns such as these have, for over a century, supported the view that the corporation, through its board of directors, has a unique vantage point from which to assess the suit's impact on the corporate interest. ${ }^{140}$

By removing section 36(b) actions from Rule 23.1, the Supreme Court reduced substantially the flexibility of lower courts to address these concerns. Even though concern for abuse in settlements and dismissals may, as some have suggested, ${ }^{141}$ be effectively dealt with by characterizing section $36(\mathrm{~b})$ actions as class actions bound by the requirements of Rule 23 , this deais with only one of the potential abuses which afflict representative suit litigation, namely the plaintiff and his representative sacrificing the class's recovery for their own personal gain.

There is an equal concern in representative litigation that the action is baseless or otherwise is harmful to the corporate interest. Protection against this harm requires pretrial screening of the suit's merits. Class action procedures, however, foreclose such review. ${ }^{142}$ Therefore, even if section 36(b) suits were subject to class action procedures, it would remain beyond

139. Fed. R. Civ. P. 23(c)(2)-(3).

140. This appears to be the principal argument of the Supreme Court cases establishing the demand requirement in America. See United States Copper Sec. Co. v. Amalgamated Copper Co., 244 U.S. 261, 263-64 (1917); Corbus v. Alaska Treadmill Goldmining Co., 187 U.S. 455, 463 (1903); Hawes v. Oakland, 104 U.S. 450,457 (1882).

141. See Note, supra note 134, at 2063-66.

142. In Doglow v. Anderson, 43 F.R.D. 472 (E.D.N.Y. 1968), rev'd and remanded for entry of facts and conclusions of law, 438 F.2d 825 (2d Cir. 1970), the court held there could be no certification of the action as a class action, unless the plaintiff established at a pretrial hearing a "substantial probability" of prevailing on the merits. Id. at 501-03. The court seemingly acted to avoid the possibility of needless and baseless adverse publicity which would follow publication of notice to the class members. Id. at 501. The court felt that if publication could occur without the plaintiff having to establish the case's substance, the defendants would be under intense pressure to settle the dispute. Id. at 501-03. The Supreme Court rejected the precertification hearing of the suit's merits in Eisen $\mathrm{v}$. Carlisle \& Jacquelin, 417 U.S. 156, 177 (1974). Moreover, there is no testing of the class action suit through a motion for summary judgment prior to the suit certification and the giving of notice when the action is, as most class actions are, maintained under FED. R. Crv. P. 23(b)(3). See Jiminezz. v. Weinberger, 523 F.2d 689, 698-99 (7th Cir. 1975). Nevertheless, there are distinct signs that courts sometimes evaluate the suit's merits, albeit covertly, in their consideration whether to certify the class action. Note, The Rule 23(b)(3) Class Action: An Empirical Study, 62 Geo. L. J. 1123, 1144 (1974). Many of those seeking reform of Rule 23 have seen the need for prescreening the class action suit's merits prior to the certification of the class. See e.g., Berry, Ending Substance's Indenture to Procedure: The Imperative for Comprehensive Revision of the Class Damage Action, 80 Colum. L. REv, 299, 313-14, 334-39 (1980); Committee on Class Actions of the ABA Section of Corporate, Banking and Business Law, Recommendations Regarding Consumer Class Actions for Monetary Relief, 29 Bus. LAw 957, 965-67 (1974); Kennedy, Federal Class Actions: A Need for Legislative Reform, 32 Sw. L.J. 1209, $1224-25$ (1979). 
the court's power to scrutinize their impact on the corporation prior to trial except through pretrial motions, which are inadequate. ${ }^{143} \mathrm{Had}$ the Supreme Court in Fox adhered to the position counselled by Justice Stevens in his concurring opinion, ${ }^{144}$ Rule 23.1 's demand on directors requirement would be inapplicable to section 36(b) actions, but its other requirements would have remained in effect and regulatory flexibility to deal with each of these concerns would have been preserved under Rule 23.1. Courts could have adopted a procedure for pretrial screening of the derivative suit's merits, which would have avoided director bias while protecting the corporate interest.

Fox is by no means alone in propounding a novel or dramatic response to the problem of collegial bias. It is distinguished by the cleanness with which it excised structural bias from the proceeding. Other judicial approaches have evolved to meet the problem of fraternal protection of an officer or director from suit. As discussed in the next section, each approach that has been propounded appears as misdirected and as poorly suited as that adopted in Fox. Courts adopting these approaches err in believing that director bias can be effectively unearthed through judicial review. In our opinion, these courts have committed the twin errors of seriously overestimating their own prowess and misconceiving the foundations of structural bias.

\section{B. The Evolving Judicial Review Standards for Committee Recommendations}

The special litigation committee was created by a melding of the business judgment rule, the demand requirement, and statutory authority for the delegation of board powers. It was intended to provide an efficient means of judging the corporate interest served by a derivative suit when the full board is otherwise disabled by self-interest from gaining the court's attention. The defendant board members' ability to handpick the members of the special litigation committee and defendants' perfect record before these committees, however, have provoked questions about both a committee's ability to render an unbiased assessment of the suit's impact on the corporate interest and the broader issue of whether directors, in any context, can be impartial when judging their colleagues' actions. The standards for review of the special litigation committee recommendations are evolving, and there continues to

143. The advent of the special litigation committee is explained by the relative inefficiencies and ineffectiveness of other pretrial devices to deflect the unwanted derivative suit. See Cox, supra note 8 , at $964-72$.

144. Daily Income Fund, Inc. v. Fox, 464 U.S. 523, 542-47 (1984). Justice Stevens reasons that Rule 23.1 does not impose a demand requirement, but rather a pleading requirement. That is, Rule 23.1 requires an allegation whether a demand has been made and it is from other sources that the court must discern whether the absence of a demand bars the suit. In Fox, the other source was section 36(b). The plaintiff satisfied Justice Stevens's interpretation of Rule 23.1 because his pleadings clearly described that no demand had been made and Justice Stevens concurred with the majority that Congress did not intend to subject the section 36(b) suit to the directors' discretion. 464 U.S. at 542-47. 
be a good deal of uncertainty surrounding these standards in many leading cases.

1. Presuming Impartiality. The most skeptical judicial response to the charge that directors are afflicted by structural bias is Auerbach $v$. Bennett, ${ }^{145}$ which holds that it is inappropriate for a court to evaluate a special litigation committee's weighing of the legal, ethical, commercial, public relations, or fiscal grounds that support its recommendation that a derivative suit be dismissed. ${ }^{146}$ In this way, Auerbach effectively confines judicial review to two narrow areas that have traditionally been open to attack by the plaintiff under the business judgment rule: the directors' independence and good faith. ${ }^{147}$ These two areas permit plaintiff challenges to the adequacy and appropriateness of the committee's procedures; the substantive bases for the committee's recommendation, however, are shielded by the business judgment rule and according to Auerbach are removed from judicial scrutiny. ${ }^{148}$

Auerbach and its progeny are important, not only for the limitations which they impose on judicial review of the committee's recommendation, but also because they stand as unwavering testimonials to a wide application of the business judgment rule and to the courts' belief that directors are devoted primarily to the corporate interest. These opinions are characterized both by insufficient attention to the commercial considerations which justify the business judgment rule's application in general business transactions and by a marked insensitivity to the threat of structural bias. Courts persuaded ${ }^{149}$ by Auerbach's articulation of the limited judicial review necessary in special

145. 47 N.Y.2d 619, 393 N.E.2d 994, 419 N.Y.S.2d 290 (1979).

146. Id. at 633,393 N.E.2d at 1002,419 N.Y.S.2d at 928.

147. Id. at $623-24,393$ N.E.2d at 996,419 N.Y.S.2d at 922.

148. See id. at 623, 393 N.E.2d at 996,419 N.Y.S.2d at 922.

149. The popularity of Auerbach may be explained more by historical accident than by courts in sister jurisdictions being persuaded by its logic. A striking statistic is that in the nearly two yearperiod between Auerbach and the Delaware Supreme Court's decision in Zapata Corp. v. Maldonado, 430 A.2d 779 (Del. 1981), which offers an alternative to Auerbach, nearly all special litigation committee cases outside New York were brought in the federal courts. See Gaines v. Haughton, 645 F.2d 761 (9th Cir. 1981), cert. denied, 459 U.S. 880 (1982); Lewis v. Anderson, 615 F.2d 778 (9th Cir. 1980); Abbey v. Control Data Corp., 603 F.2d 724 (8th Cir. 1979), cert. denied, 444 U.S. 1017 (1980); Genzer v. Cunningham, 498 F. Supp. 682 (C.D. Mich. 1980); Rosengarten v. International Tel. \& Tel. Corp., 466 F. Supp. 817 (S.D.N.Y. 1979). Federal courts, even for actions raising a federal question, must first determine the appropriate review standard under applicable state law. Burks v. Lasker, 441 U.S. 471, 480 (1979). When these federal courts were required to decide the level of review appropriate for a special litigation committee's recommendation, there were only two other state court decisions besides Auerbach that involved committee recommendations. In one, the committee's recommendation was easily ignored because an egregious lack of independence on the part of the committee members was clearly reflected in the record. Swenson v. Thibaut, 39 N.C. App. 77, 106-07, 250 S.E.2d 279, 298 (1978). In the only other committee-related decision, the court delayed until a later hearing its consideration of the effect and standard of review appropriate for a committee recommendation. Sonics Int'l, Inc. v. Dorchester Enters., Inc., 593 S.W.2d 390 (Tex. Civ. App. 1980). Auerbach, therefore, was the only state court decision available on which federal courts could rely in defining the deference, if any, to be extended to a committee's recommendation. These post-Auerbach federal decisions contrast with the much closer review of committee recommendations and more balanced approach toward functions of the business judgment rule exhibited in pre-Auerbach cases. See Cramer v. General Tel. \& Elec., 582 F.2d 259 , 
litigation committee cases have in effect announced a substantial presumption that the committee has acted properly, so that its recommendation can be overturned only in extreme situations. ${ }^{150}$

2. Questioning the Appointive Process. In contrast to Auerbach, Miller v. Register E Tribune Syndicate, Inc. ${ }^{151}$ expressed the fear that even the most finely tuned adversative inquiry could not clearly distinguish rationally drawn conclusions from collegial bias. The issue in Miller was whether a committee whose members were all nominated to the board after the derivative suit's commencement could cause that suit's dismissal. The Iowa Supreme Court held it could not. ${ }^{152}$ The Miller court's approach, while not so sweeping as that of the Supreme Court in Fox, nevertheless singled out a specific situation in which committee recommendations were disallowed:

We believe that the potential for structural bias on the part of a litigation committee appointed by directors who are parties to derivative actions is sufficiently great and sufficiently difficult of precise proof in an individual case to require the adoption of a prophylactic rule. We conclude that we should prevent the potential for structural bias in some cases by effectively limiting the powers of such directors in all cases. ${ }^{153}$

Miller is a welcome break from decisions that have shown no sensitivity to the potential inherent in the appointive process. It reflects not only a popular concern that the defendants will "shop" for "right thinking" individuals to serve as their jurors, but also addressses the more subtle bias, described earlier, ${ }^{154}$ arising from the fact that appointment itself bestows a reward upon the committee members who thereafter can be expected to conform their beliefs to those understood to be acceptable to their appointers. Miller, therefore, represents a needed refinement in current practices by defining director independence in terms other than their involvement in the underlying wrongdoing.

Miller nevertheless recognizes the legitimacy of the special litigation committee as a pretrial procedure. The court was willing to use its equity power to staff a committee free of the defendants' hand in the selection. ${ }^{155}$ Its concern is therefore limited to the process of staffing the committee and did not reach other sources of bias that are present even among committee members selected by an outside party.

274-76 (3d Cir. 1978), cert. denied, 439 U.S. 1129 (1979), and Gall v. Exxon Corp., 418 F. Supp. 508 (S.D.N.Y. 1976).

150. In Hasan v. CleveTrust Realty Investors, 548 F. Supp. 1146, 1149 (N.D. Ohio 1982), the court, as in Auerbach, required actual proof of director bias to establish the lack of the director's good faith. The fact that the committee report was deficient, but not materially so, was thus not sufficient to impeach the committee's impartiality. Id. at 1148-49: The Sixth Circuit Court of Appeals rejected the district court's presumption of the committee members' good faith without rejecting Auerbach's position on court review of the substance of the committee's recommendation. Hasan v. Cleve Trust Realty Investors, 729 F.2d 372, 376 (6th Cir. 1984)

151. 336 N.W.2d 709 (Iowa 1983); see also Alford v. Shaw, 72 N.C. App. 537, 324 S.E.2d 878 (1985).

152. Id.

153. Id. at 718

154. See supra text accompanying note 59.

155. Miller, 336 N.W.2d at 718 . 
If the directors in Miller had been appointed by a court, the Miller court would have accepted the committee's recommendation. ${ }^{156}$ Similarly, in Stein $v$. Bailey, ${ }^{157}$ the court reasoned that the independence of a committee containing only a minority of the board is inherently suspect and therefore decided that a court should require the committee to provide persuasive evidence of their independence and disinterestedness. ${ }^{158}$ Both Miller and Stein are consistent with the view that director bias is subtle and must be handled prophylactically. Miller selects the more drastic prophylaxis. In neither case, however, did the court hold that inspection of the committee's report was to be the sole means available for dealing with director bias. Their threshold concern for independence focused exclusively upon the selection and composition of the committee.

Courts adhering to Auerbach may also be concerned about director independence, but they are hobbled in evaluating bias by their general assumptions about director behavior. Thus the two lines of cases disagree not only about what is the correct approach in dealing with questionable, but undocumented, director bias, but also about what factors should stimulate the court's concern. Because the question of director independence is distinct from a more global inquiry about the directors' good faith, it can be resolved by examining the relationships a director has with the defendants, the law suit, and the corporation. We believe that this examination should follow the lines of inquiry offered in the first section of this paper. For example, how are the directors appointed? What are their contacts with the defendants, and how similar are their overall backgrounds? These are broader concerns than those suggested by Auerbach, implying that Auerbach's articulation of an independence requirement is primarily an empty prayer. The approach in Miller, although drastic, is consistent with the purpose to be served by a threshold requirement of director independence.

Shifting the burden of proof about committee members' connections to the suit or the defendants will, under appropriate standards of independence, produce the same result as asking if they can render an independent opinion worthy of the court's consideration. Thus, the distinction between Miller and Stein reflects primarily differences over the sources of director independence. The objective should be to determine not who has the burden of proving the presence or absence of suspect relations, but what those suspect relationships are and how to establish an independent special litigation committee.

156. Id.

157. Stein v. Bailey, 531 F. Supp. 684 (S.D.N.Y. 1982) (majority of the sitting directors were independent but delegated to a committee the task of preparing the board's response to plaintiff's demand).

158. In other cases where a corporation's response to a demand is proffered through a committee, even though a majority of the board is not disqualified to respond to the demand, the committee has not been required to establish its independence. See Abramowitz v. Posner, 672 F.2d 1025 (2d Cir. 1982); Mills v. Esmark, Inc., 544 F. Supp. 1275 (N.D. Ill. 1982). Some commentators have argued that committee recommendations may' be ignored, regardless of when or how the committee is elected, whenever a majority of the board of directors is not independent. Coffee \& Schwartz, supra note 119, at 320-26. 
Nevertheless, independence is, under contemporary standards, only a threshold consideration directed toward limiting the most blatant sources of director bias. Further tests are needed to preclude subtle biases.

3. Dispatching Skepticism through Judicial Review. The possible sources of director bias recognized by the Delaware Supreme Court in Zapata Corp. $v$. Maldonado ${ }^{159}$ were broader in scope than those expressed in Miller. The Zapata court observed:

$[\mathrm{N}]$ otwithstanding our conviction that Delaware law entrusts the corporate power to a properly authorized committee, we must be mindful that directors are passing judgment on fellow directors in the same corporation and fellow directors, in this instance, who designated them to serve both as directors and committee members. The question naturally arises whether a "there but for the grace of God go I" empathy may not play a role. And the further question arises whether inquiry as to independence, good faith and reasonable investigation is sufficient safeguard against abuse, perhaps subconscious abuse. ${ }^{160}$

Zapata, however, did not include Miller's sweeping solution. While recognizing a serious threat of director bias, the Zapata court reasoned that judicial review of a committee's recommendation should not eviscerate the valuable role the directors' judgments of a suit's worth can play in derivative suit litigation. The court charted what it believed to be a middle course between allowing committee recommendations so much deference that the derivative suit is mortally wounded, on the one hand, and being so skeptical of the committee that the corporation is totally unable to rid itself of a harmful suit, on the other. Into this breach, the Delaware Supreme Court flung a two-step test.

Under Zapata's first step, the court evaluates the committee members' independence, good faith, and bases for their recommendation. ${ }^{161}$ Zapata reinforced these requirements by demanding a detailed report of the committee's investigation procedures and findings, by placing the burden of establishing these factors on the committee, and by subjecting the committee's reasoning to close scrutiny. ${ }^{162}$ This scrutiny represents the court's most sweeping response to the threat of structural bias. In its second step, Zapata invited the reviewing court to exercise its independent judgment in determining whether the corporate interest is served by the derivative suit's continuance. ${ }^{163}$ This discretion is to be exercised only in limited instances, however. ${ }^{164}$

The criteria Zapata proposed unfortunately are quite vague, so that achieving Zapata's objectives primarily depends on the reviewing court's general concern for structural bias. Zapata offers no insight into the meaning of any of the first-level standards. Potentially the standards of

159. 430 A.2d 779 (Del. 1981).

160. Id. at 787 .

161. Id. at $788-89$.

162. See id.

163. Id. at 789 .

164. See infra text accompanying notes 171-75. 
"independence," "good faith," and "reasonable bases" could be interpreted and applied to generate more penetrating inquiry into the committee's actions than the inquiry likely to result using the standards of Auerbach. Such application would be consistent with the approach used in Miller. Indeed, Miller's ${ }^{165}$ decision to ignore the recommendation of a committee whose members were selected by the defendants after the suit was initiated is essentially an application of a demanding independence standard. ${ }^{166}$

The good faith inquiry coupled with the requirement that the committee must articulate in its report detailed bases for its recommendations has proven to be the most significant aspect of Zapata. The importance of these twin requirements is amply illustrated in Mills $v$. Esmark, Inc., ${ }^{167}$ a case technically not within Zapata's two-step approach because a demand was required in Mills, whereas Zapata reserves its two different levels of analysis for cases in which a demand on the board has appropriately been excused. ${ }^{168}$ In Mills, the corporation's response to the demand came from a committee. Because it was a demand-required case, there was reason to believe the court's review would be similar to that in Auerbach, where the plaintiff had not been permitted to challenge the committee's presumed good faith by demonstrating dissonance between the committee's report and the actual facts. ${ }^{169}$ Nevertheless, in Mills the plaintiff was allowed to question the committee's good faith by articulating specific areas where the committee's treatment appeared inconsistent with facts uncovered by the plaintiff. ${ }^{170}$ The Mills court concluded correctly that inquiry into the committee's treatment of the facts and resolution of the suit's merits was a necessary means to determine the committee's good faith.

Mills's more demanding consideration of good faith is in stark contrast to Auerbach and reflects the court's greater sensitivity to structural bias as a recognition of Zapata's elevation of this concern. Thus, the impact of the

165. Miller v. Register \& Tribune Syndicate, Inc., 336 N.W.2d 709 (Iowa 1983), discussed supra text accompanying notes 151-55.

166. This was once the position of the proposals now under consideration by the American Law Institute. American Law Institute, Principles of Corporate Governance and Structure: Restatement and Recommendations $\S 7.03(\mathrm{e})$ (Tent. Draft No. 1, 1982).

167. 544 F. Supp. 1275 (N.D. Ill. 1982).

168. See Zapata Corp. v. Maldonado, 430 A.2d 779, 787 (Del. 1981). When a demand on the board is not excused, the directors' recommendation is sustained, unless the plaintiff rebuts the committee's presumed independence, good faith, and use of reasonable procedure. Abramowitz $v$. Posner, 672 F.2d 1025, 1031 (2d Cir. 1982); accord Aronson v. Lewis, 473 A.2d 805, 812 (Del. 1984).

169. See, e.g., Hasan v. CleveTrust Realty Investors, 729 F.2d 372 (6th Cir. 1984); Galef v. Alexander, 615 F.2d 51, 56 (2d Cir. 1980); Rosengarten v. International Tel. \& Tel. Corp. 466 F. Supp. 817, 823 (S.D.N.Y. 1979); Gall v. Exxon Corp., 418 F. Supp. 508, 520 (S.D.N.Y. 1976). But see Genzer v. Cunningham, 498 F. Supp. 682 (E.D. Mich. 1980).

170. See Mills v. Esmark, Inc., 544 F. Supp. 1275, 1283-87 (N.D. Ill. 1982). While Mills entertained inquiry into the committee's good faith through examination of facts raised by the plaintiff, its disposition of the issues raised by the plaintiff leaves much to be desired. The court refused to discredit the committee's presumed good faith in the face of important deficiencies in the committee's deliberations concerning facts raised in the plaintiffs depositions of the committee members. These deficiencies were presumed by the court to be not symptomatic of bias within the committee when it formulated the report, but merely the result of a lack of detachment once the conclusion was reached. Id. at 1284 n.8. 
Zapata standard is dependent not upon its articulation, but on the strength of the reviewing court's sensitivity to bias.

The content and application of Zapata's second step, in which the court can exercise its own independent judgment, ${ }^{171}$ are even more elusive than the first-step analysis. Zapata envisions that in the second-step analysis a reviewing court may reject the committee's finding that the corporation's interest is best served by dismissal. Or, even if the court agrees that the corporate interests are served by dismissal, other considerations of public policy may override parochial corporate interests and justify continuance of the suit. ${ }^{172}$ The reviewing court's exercise of this power was intended by Zapata to be discretionary. That discretion, however, appears to have been somewhat circumscribed by Zapata's own language. First, Zapata suggests that its secondstep analysis is intended to produce serious consideration of how compelling is the corporate interest served by dismissal only when the suit is nonfrivolous. ${ }^{173}$ The court also envisions that the second-step analysis will balance the committee's articulation of the corporate interest served by dismissal against the presence of a legitimate corporate claim. ${ }^{174}$ Both statements confine the court's application of its second-step independent judgment to cases in which, after review of the committee's report under the first step, the court is satisfied that there exists a prima facie cause of action and that the corporate interest served by the suit is consistent with the costs and benefits of continuing the suit. ${ }^{175}$

The syntax of Zapata's two-step analysis suggests that greater deference be accorded a committee's recommendation in the first step than in the second step. As seen above, the court's independent judgment, exercised at the second step, is reserved for nonfrivolous cases. Frivolity no doubt is in the eye of the beholder. To be sure, it is neither necessary nor appropriate under Zapata for a court to exercise its own independent judgment in step two when

171. 430 A.2d at 789 .

172. Id.

173. Id.

174. Id.

175. Abella v. Universal Leaf Tobacco Co., 546 F. Supp. 795 (E.D. Va. 1982), describes another instance in which a court may exercise its independent judgment to reject a committee's dismissal recommendation, namely when the "plaintiff just lacks the resources, determination, or information necessary in order to prosecute a meritorious claim on behalf of the corporation." Id. at 802 . Abella itself, however, appears to be the victim of this kind of information imbalance. In Abella, the plaintiff lacked such vigor, having conducted only one deposition in the entire suit, a deposition that was not directed against the committee. Id. Absent an adversary hearing in which the coherence of a committee's recommendation, facts, and findings could be tested by a plaintiff armed with information garnered through discovery, there appears to be no reasonable way a court can render a reliable determination that either Zapata's first or second level has been satisfied. Abella recognizes this in its suggestion that the court may delay or ignore a committee's recommendation when the plaintiff has been financially unable to launch a reasonable assault on the committee or underlying facts. Id But the instances when such a result would occur are difficult to imagine. The plaintiff's poor resources or lack of zeal is too often consistent with the view that the suit lacks merit. The more likely result is that which occurred in $A$ bella, in which the court accepts the committee's unchallenged version of the facts. The court's dismissal is more suitably catalogued as a dismissal for lack of prosecution than as a ringing victory for the directors' ability to assess impartially the corporate interest. 
it concurs in the committee's assessment that the suit lacks merit. Unanswered in Zapata, however, is how deeply the court should probe the committee's report at step one, in making its threshold determination of the suit's merits, before it can advance to the second-step analysis. The Delaware Supreme Court's concern that directors retain some power to deflect a wasteful derivative action ${ }^{176}$ suggests an approach in which deference is extended to the committee's opinion on the merits, except when a prima facie case can be established solely on the basis of the committee's report showing that the committee's dismissal recommendation is grounded on weak considerations such as the suit's incidental costs exceeding its benefits. ${ }^{177}$ Zapata may well envision that the committee's view of the suit's merits should enjoy the same level of deference courts extend to director judgments in other areas in which directors are, under the reasonable basis criterion, free to select from among several reasonably supported alternatives. ${ }^{178}$

There is good reason to doubt that Zapata provides an adequate formula for coping with structural bias in the boardroom. It invokes the traditional, weak standards for measuring the directors' independence, and it assesses their good faith in a proceeding constrained by the necessity that it be more economical than a full scale trial. Moreover, Zapata's second step may serve only to underscore the deference to be accorded the committee's report under the first step. In this respect, it is interesting that among the cases which have rejected committee dismissal recommendations no qualitative difference appears whether Zapata is applied or not. ${ }^{179}$ In each instance, the committee report is defective on its face because, for example, the report was either inconsistent or incomplete in its findings or conclusions. What appears evident from these cases is that the precise formulation of the review process is not nearly as important as is the court's willingness to entertain an assault

176. 430 A.2d at $786-87$.

177. See, e.g., Abramowitz v. Posner, 513 F. Supp. 120, 123-24, $131-32$ (S.D.N.Y. 1981), affd, 672 F.2d 1025 (2d Cir. 1982), where the court recognized a probability of securing a favorable judgment but recommended against the suit's continuance in recognition of the defendant's extraordinary services to the corporation, significant remedial action, and concomitant publicity. See also Lewis v. Anderson, [1981-1982 Transfer Binder] FED. SEC. L. REP. (CCH) \98,455 (C.D. Cal. 1981).

178. For example, in Elfenbein v. American Fin. Corp., 487 F. Supp. 619 (S.D.N.Y. 1980), the court held that the directors of a parent corporation had a reasonable basis for their exercise of warrants in a subsidiary corporation because they relied on counsel's opinion that the exercise presented no perils under the tax laws even though two other experts disagreed. The court in Muschel v. Western Union Corp., 310 A.2d 904, 908-09 (Del. Ch. 1973), held that the decision of an acquiring corporation's directors that a merger's terms were fair was reasonably based on a projection of the earnings of the companies as combined entities even though a projection of the individual companies' earnings suggested that the terms were unfair. See also Panter v. Marshall Field \& Co., 486 F. Supp. $1168,1180,1194$ (N.D. Ill. 1980), affd, 646 F.2d 271 (7th Cir.), cert. denied, 454 U.S. 1092 (1981) (directors armed with opinion of counsel that bidder for control posed serious antitrust problems had reasonable basis for defensive maneuvers even though ample evidence indicated that antitrust issues could be resolved); Warshaw v. Calhoun, 43 Del. Ch. 148, 159, 221 A.2d 487, 492 (1966) (alternative financing plans all deemed reasonable; choice among plans was a matter of director discretion). See generally Arsht, Business Judgment Rule Revisited, 8 HofsTrA L. REv. 93 (1979).

179. See, e.g., Hasan v. CleveTrust Realty Investors, 729 F.2d 372 (6th Cir. 1984); Holmstrom v. Coastal Indus., Inc., [1984 Transfer Binder] Fed. Sec. L. ReP. (CCH) १ 91,486 (N.D. Ohio 1984). 
on the committee's report, even if that challenge occurs solely through the court's efforts.

4. "Valuing" the Suit. Significantly, post-Zapata decisions fail to recognize the discretionary aspect of Zapata's second step. Courts purporting to follow Zapata have instead interpreted Zapata to require their exercise of independent business judgment in all cases. ${ }^{180}$ The most insightful application of this interpretation of Zapata was by the Second Circuit in Joy $v$. North, ${ }^{181}$ which offered the following description of the reviewing court's function:

$[T]$ he burden is on the moving party, as in motions for summary judgment generally, to demonstrate that the action is more likely than not to be against the interests of the corporation ... . [T] The function of the court's review is to determine the balance of probabilities as to likely future benefit to the corporation, not to render a decision on the merits, fashion the appropriate legal principles or resolve issues of credibility. Where the legal rule is unclear and the likely evidence in conflict, the court need only weigh the uncertainties, not resolve them. The court's function is thus not unlike a lawyer's determining what a case is "worth" for purposes of settlement. 182

The approach advocated in Joy is light years beyond the uncritical evaluation embraced in Auerbach. Minimally, the Joy approach is a more fully textured description of the review process initially proposed in Zapata. Moreover, Joy is a rare instance in which a court has refused to follow a committee's recommendation and dismiss a derivative action on the substance of the committee's report. ${ }^{183}$

180. See, e.g., Joy v. North; 692 F.2d 880, 888-89 (2d Cir. 1982), cert. denied, 460 U.S. 1051 (1983); Maldonado v. Flynn, 67 I F.2d 729, 732 (2d Cir. 1982); Abella v. Universal Leaf Tobacco Co., 546 F. Supp. 795, 801 (E.D. Va. 1982); Watts v. Des Moines Register \& Tribune, 525 F. Supp. 1311, 1329 (S.D. Iowa 1981). In both Watts and Maldonado, the two earliest post-Zapata cases, the courts, even though satisfied that the committees acted in good faith and were independent, did not grant their recommendations that the suits be dismissed because each committee failed to offer an adequate explanation of its reasoning. The result in each case, however, turned on unique procedural configurations and not on the court's actual exercise of an independent business judgment. The committee in Maldonado formulated its recommendation before Zapata was decided and accordingly failed to offer more than the customary list of general grounds for dismissal without factual support of its conclusions. In Watts, the plaintiff's power to challenge the committee's recommendation had been curbed by the limited discovery permitted by the federal magistrate, so that no action was taken in response to the committee's recommendation until the plaintiff was permitted to discover the factors which influenced the committee's recommendation. $525 \mathrm{~F}$. Supp. at 1329. The Watts court interpreted Zapata to extend to the derivative suit plaintiff greater discovery powers than under the contrasting Auerbach standard. Id. The Watts court also was concerned that the committee did not explain why.it deviated from its counsel's advice that the derivative suit be continued for one of the counts alleged against the defendants. This inconsistency was singled out by the district court for scrutiny at the hearing to occur after plaintiff's discovery against the defendants. Id. Abella, as discussed supra note 184 , can best be understood as the court's acceptance of the committee's perspective on the dispute essentially because of the plaintiff's failure to prosecute the case diligently. The court's examination of the facts, when it purported to exercise its own independent judgment, is more consistent with the view that the court satisfied itself that there was a reasonable basis for the committee's recommendation than it is with the overall persuasiveness of the committee's recommendation. Delaware continues, however, to view the second-step analysis as being a matter of discretion. Kaplan v. Wyatt, 484 A.2d 501, 508-09 (Del. Ch. 1984).

181. 692 F.2d 880 (2d Cir. 1982), cert. denied, 460 U.S. 1051 (1983).

182. Id. at 892.

183. One other case has rejected the committee's recommendation because of substantive considerations in the committee's report. See Holmstrom v. Coastal Indus., [1984 Transfer Binder] 
The complaint in Joy arose from loans made by Citytrust Bankcorp, Inc. to Katz, a developer in precarious financial condition. The loans ultimately exceeded the maximum limit permitted by the National Bank Act ${ }^{184}$ to a single borrower. Katz's default caused Citytrust to absorb a certain loss of more than five million dollars. ${ }^{185}$ The special litigation committee was established nearly two years after the derivative suit was commenced. The committee, after nine months, recommended dismissal of the derivative suit against the twenty-three "outside" defendants, concluding that there was "no reasonable possibility" they would be held liable. ${ }^{186}$ As for the remaining seven "inside" defendants, who were senior officers of Citytrust and therefore deeply involved in approving the Katz loans, the committee's recommendation was equivocal. The committee reasoned that there was a "possibility" the "inside" defendants had acted negligently and recommended that settlement negotiations be undertaken with the "inside" defendants. The committee nevertheless cautioned that its recommendation that settlement negotiations were appropriate did not necessarily imply that the committee believed continued litigation against the "inside" defendants served the corporate interest. ${ }^{187}$

The Joy court's review of the committee's dismissal recommendation nicely frames the dilemma that a special litigation committee poses to a court responding to a recommendation that the derivative suit be dismissed. The court was forced to choose between accepting a committee's evaluation of law and facts, contaminated in some indeterminate amount by the directors' bias, or pursuing a final resolution of the legal and factual uncertainties through costly litigation of the claim. The special litigation committee's potential contribution toward shortening the course of wasteful litigation lies in cases such as Joy where the suit's outcome is problematic at the pretrial stage. This situation arises when, on the one hand, the conclusions to be drawn from the facts-such as the defendants' involvement in the alleged wrongdoing or the existence of a business purpose which would exonerate them-remain uncertain even after pretrial investigation or, on the other hand, when the applicable legal duties and defenses are evolving and therefore indefinite. ${ }^{188}$

FED. SEC. L. REP. (CCH) 991,486 (N.D. Ohio 1984). Another case delayed any action in response to a committee's report until the committee further developed its reasons for recommending dismissal. Watts v. Des Moines Register \& Tribune, 525 F. Supp. 1311, 1327-29 (S.D. Iowa 1981). And three other cases have rejected the committee's recommendation because its independence and good faith were doubted. Hasan v. CleveTrust Realty Investors, 729 F.2d 372, 379 (6th Cir. 1984); Miller v. Register \& Tribune Syndicate, 336 N.W.2d 709, 718 (Iowa 1983); Swenson v. Thibaut, 39 N.C.App. 77, 107, 250 S.E.2d 279, 298 (1978); see also recommendations of suit against noncolleagues catalogued supra note 97.

184. 12 U.S.C. $\$ 84$ (1982).

185. 692 F.2d at 895 .

186. Id. at 884 .

187. Id.

188. This is an insight overlooked recently by the Delaware Chancery Court. Chancellor Brown in Kaplan v. Wyatt, 484 A.2d 501 (Del. Ch. 1984), observed that special litigation committees are wasteful because they contribute toward "litigation within litigation." Id. at 511 . Chancellor Brown is also of the belief, however, that a committee's dismissal recommendation must be rejected if material facts are in dispute. Id. at 508. If this observation were correct, his disdain for the 
When neither the facts nor the law are disputed, however, the special litigation committee adds little to the defendants' arsenal for ridding themselves of a wasteful derivative suit during the pretrial stage. The more conventional pretrial motion for summary judgment (aided by uncontroverted affidavits) or motion to dismiss are available to dispose of the suit. ${ }^{189}$

Therefore, if the special litigation committee is to foreshorten wasteful derivative suit litigation, uncertainty about legal doctrines and factual evidence should not disqualify a committee's recommendation. Joy raised both of these concerns, relying upon each source of uncertainty to reject the committee's recommendation. The defendants' involvement with the Katz loan and the degree of nonvigilance by each of the outside defendants were necessarily issues requiring factual inquiry. The conclusion about each defendant would depend upon witness credibility, inferences drawn from the facts, and the effectiveness of counsel. Moreover, the applicable legal principles were not free of doubt in Joy. The outside directors' duty to monitor the loan officers' performance and to respond to events threatening the corporate interest are today perceived to demand of outside directors a higher standard of behavior than was required of outside directors in earlier years. ${ }^{190}$ These uncertainties were emphasized in Joy's rejection of the

committee as a prescreening device is justified. On the other hand, if his concept of material facts being in dispute is that the committee report is either inconsistent, incomplete, or unpersuasive, then these are proper bases to reject the committee's recommendations quite apart from the case in which the plaintiff and committee have different understandings of the facts or law. In the latter situation, the committee should not be viewed as a dysfunctional prescreening device.

189. This conclusion is illustrated by the result reached in many pre-Auerbach decisions in which liability was under the federal securities laws against directors and officers for questionable payments. Federally-based claims were as easily disposed of when the defendants themselves sought dismissal on a motion to dismiss or for summary judgment as when dismissal was sought by a special litigation committee. When suit was based on a violation of the periodic reporting requirements mandated by section 13(a) of the Securities Exchange Act, 15 U.S.C. $\$ 78 \mathrm{~m}(\mathrm{a})$ (1982), courts concluded there was no private right of action under the provision. See, e.g., In re Penn Cent. Sec. Litig., 494 F.2d 528, 540-41 (3d Cir. 1974); McLaughlin v. Campbell, 410 F. Supp. 1321, 1325 (D. Mass. 1976); duPont v. Wyly, 61 F.R.D. 615, 628 (D. Del. 1973). Under proxy solicitation rules of section 14(a) of the Securities Exchange Act, 15 U.S.C. $\$ 78 \mathrm{n}$ (a) (1982), there is an implied private right of action. The courts have upheld dismissals for failure to disclose bribery practices, however, because of a want of causation between the alleged nondisclosure and the injury sought to be redressed (recoupment of monies or ordering a new election). See, e.g., Gaines v. Haughton, 645 F.2d 761, 776 (9th Cir. 1981), cert. denied, 454 U.S. 1092 (1982); Herman v. Beretta, [1978 Transfer Binder] FED. SEC. L. ReP. (CCH) ๆ 96,574 (S.D.N.Y. 1978); Limmer v. General Tel. \& Elec., [1977. 1978 Transfer Binder] FED. SEC. L. REP. (CCH) 96,111 (S.D.N.Y. 1977). The pattern of analysis is no different where a committee has considered the problem of questionable payments and recommended dismissal. See Abbey v. Control Data Corp., 603 F.2d 724, 732 (8th Cir. 1979), cert. denied, 444 U.S. 1017 (1980); Rosengarten v. International Tel. \& Tel. Corp., 466 F. Supp. 817, 82829 (S.D.N.Y. 1979).

190. While the obligation of directors to inform themselves generally of the corporation's affairs and financial position is well established, see Barnes v. Andrews, 298 F. 614 (S.D.N.Y. 1924), their duty to establish systems to detect illegal or improper conduct by officers or employees is confused by the restrictive view of the question taken by the leading case, Graham v. Allis-Chalmers $\mathrm{Mfg}$. Co., 41 Del. Ch. 78, 188 A.2d. 125 (1963). Because of the passage of time since Graham was decided, during which the political and social environment of business has undergone dramatic changes, scholars differ regarding whether Graham would be decided differently today. Compare Veasey \& Manning, Codified Standard -Safe Harbor or Unchartered Reef?: An Analysis of the Model Act Standard of Care 
committee's recommendation. The court stressed that conflicting versions of the facts might have to be resolved. ${ }^{191}$ Furthermore, the court indicated that the guiding legal principles were quite general, so they could be interpreted as reaching the defendant's conduct. ${ }^{192}$ Clearly these observations were justified by the case's record; indeed, they were inherent in the nature of the dispute. They should not, however, be independent bases to ignore a committee's dismissal recommendation.

Joy's treatment of the committee's recommendation reminds us that meaningful standards for judicial review of director recommendations have yet to be developed. Joy's expression of these standards in terms of the reviewing court's deciding a suit's "worth,"193 while consistent with its view that a court should exercise its own independent business judgment, is nevertheless vague and, in fact, devoid of content. Indeed, Joy's review is more consistent with Zapata's admonition that the review procedure is analogous to a court's response to a motion for summary judgment. ${ }^{194}$ The Joy court's rejection of the committee's recommendation was premised upon significant differences between the committee's version of the facts and law of the dispute and those which may possibly be established at trial. As reasoned above, such a review standard adds little to existing pretrial procedures and restricts the usefulness of the special litigation committee in protecting the corporate interest by shortening wasteful litigation. At the same time, Joy's recognition that the court should determine the suit's "worth" where uncertainties abound appears to require upholding a committee recommendation even when there are significant differences of fact and law. ${ }^{195}$ Nevertheless, Joy neither weighed the possible contrasting legal and factual interpretations nor valued the suit's possible outcomes. ${ }^{196}$ For this reason, Joy's review standards seem to be much more consistent with the summary judgment approach referred to in Zapata than to Joy's own "worth" standard. ${ }^{197}$

Compared with Delaware Law, 35 Bus. LAw. 919, 930 n.53 (1980), with Ward, Fiduciary Standards Applicable to Officers and Directors and the Business Judgment Rule under Delaware Law, 3 DEL. J. CoRP. L. 244 (1978). The proposals to the ALI envision that directors have an affirmative duty to be reasonably concerned with the existence and effectiveness of programs designed to oversee the corporation's affairs. American Law Institute, Principles of Corporate Governance: Analisis and Recommendations | 4.01 , at 44-48 (Tent. Draft. No. 3, 1984).

191. 692 F.2d at 894 .

192. Id. at 896 ("Applying the standard of review set out above to the Committee recommendation, we look first to potential liability generally without regard to which defendants are responsible.").

193. Id. at 892. A potential problem with an approach in which the suit's mean expected return is estimated by the weighted average of its possible outcomes (with the weight assigned each outcome being its probable occurrence), and the decision to continue assessed in terms of whether that mean expected return is greater than the suit's cost, is that where very large damages accompany an outcome with a low probability of occurrence the suit could be considered to have sufficient worth to merit its continuance, even though it is a "long shot." See Corporate Governance. supra note $120, \S 7.08(\mathrm{a})(3)(\mathrm{B})$.

194. Zapata Corp. v. Maldonado, 430 A.2d 779, 787 (Del. 1981).

195. But see Kaplan v. Wyatt, 484 A.2d 501 (Del. Ch. 1984), discussed supra note 188.

196. See 692 F.2d at $894-97$.

197. See supra note 188 . 
A court's response to the directors' rejection of a demand or a committee's dismissal recommendation should be different from its evaluation of a proposed settlement of a derivative suit. ${ }^{198}$ While the criteria used by courts in considering whether to approve a settlement examine factors bearing on a suit's "worth," the settlement paradigm is functionally distinct from the court's review of the directors' rejection or recommendation. Settlements are understood to involve compromises by each party. ${ }^{199}$ Weaknesses in the plaintiff's case are expected to be traded for lower recovery, while weaknesses in the defense's case are believed to increase the settlement. In this way, the litigants' combined estimates of the suit's worth are incorporated into a single settlement figure. ${ }^{200}$ When a demand is rejected by the directors, or dismissal recommended by a committee, there are no trade-offs between the strengths and weaknesses of each party's case. In that situation, it is inappropriate for a court to inquire whether each side has made a suitable compromise or to defer heavily to the parties' arms-length negotiations as assurance of overall fairness. Only if the interests of directors or committee interests were adverse to those of the defendants, an assumption not supported by the first section of this article, could there be a sound basis for using the settlement review paradigm. Furthermore, the record of directors and committees shows that they look not toward compromise, but rather toward ridding the corporation and the defendants of the derivative suit, regardless of its potential worth.

Despite its extensive description of how a court should evaluate a suit's worth, Joy did not consider whether the suit's expected return exceeded its probable costs in its rejection of the committee's recommendation. The court was guided instead by weaknesses on the face of the committee's report in which the committee's reasoning was both inconsistent and incomplete. Because the report was flawed, it was unnecessary for the court to weigh the suit's costs and benefits to determine whether continuance of the suit was in the corporation's interest. In this way, Joy bears witness to the potential strengths of Zapata's first step, particularly before a court genuinely concerned with the risks of collegial bias, and not to the significance of Zapata's second step.

Joy's treatment of the committee's report raises again a question whether any meaningful difference exists in the nature and the purpose of Zapata's first and second steps. Cases to date have yet to produce a result in which a court has upheld the committee under Zapata's first step but rejected the recommendation under its second step. Because the committee's bias is examined at the first step by searching for dissonance among the facts,

198. For a review of settlement criteria, see, e.g., Shlensky v. Dorsey, 574 F.2d 131, 147-49 (3d Cir. 1978); City of Detroit v. Grinnell Corp., 495 F.2d 448 (2d Cir. 1974); Greenspun v. Bogan, 492 F.2d 375 (1st Cir. 1974); see also Haudek, The Settlement and Dismissal of Stockholders'Actions-Part II: The Settlement, 23 Sw. L.J. 765, 792-801 (1969).

199. Haudek, supra note 198, at 794-96. This approach is also counselled in designing a rational litigation strategy. See R. Posner, Economic Analysis of Law 434-41 (2d ed. 1977); H. Ross, SetTled Out of Court (1970).

200. See Ross, supra note 199; Posner, supra note 199. 
findings, and conclusions contained in its report, it seems highly unlikely that a court could uphold the committee's version of these matters and still reach a different conclusion respecting the suit's worth. In this way, Zapata's and Joy's exhortations for courts to exercise their own independent judgment of the suit's worth seem to offer nothing more than an illusory step in the court's review of the committee's recommendation. The false promise of Zapata's second step is not troubling if it is assumed that each committee whose judgment is deflected by structural bias will commit the unpardonable sin of rendering a report defective on its face. The concern whether the directors' bias will always give rise to a facially defective report arises because inherent in any prescreening procedure is the need to limit the degree of discovery against the committee as well as the range of matters inquired into at any hearing convened to challenge the report. ${ }^{201}$ These procedural limitations may well heighten the importance of the talents brought to bear in the report's preparation. Hence, there may well lie within the Zapata-type review a second type of bias: The well-recognized structural bias may be joined by a bias inherent to the abbreviations that occur in the review process.

5. Coming Full Circle with the ALI. The proposals to the American Law Institute in its ongoing corporate governance project are both visionary and myopic, an affliction unsettling to those who look to the ALI for guidance. The proposals are visionary in the unqualified choice made by the ALI to join the ranks of commentators ${ }^{202}$ (but not the courts ${ }^{203}$ ) who have counselled that the same review standards should apply to demand-required cases as are applied to committee recommendations in demand-excused cases. The proposals carry forward the demand-on-directors requirement ${ }^{204}$ and confine the bases for excusing these demands. ${ }^{205}$ However, later provisions ${ }^{206}$ trivialize the operational effects of making a demand. The purpose of demand is no longer to provide the target toward which the defendant's colleagues direct their shared beliefs that the suit is not in the corporation's best interest; under the proposal, the response to the suit occurs through a recommendation proffered independently of the demand. The recommendation is made by a committee of directors chosen by the board ${ }^{207}$ or, upon the corporation's request, by a committee of nondirectors chosen by the court. ${ }^{208}$ The Reporters have thereby tailored the demand requirement's effects so that the act of making a demand serves as a means for corrective

201. See Watts v. Des Moines Register \& Tribune, 525 F. Supp. 1311 , 1329 (S.D. Iowa 1981); Kaplan v. Wyatt, 484 A.2d 501, 509-12 (Del. Ch. 1984).

202. See, e.g., Cox, supra note 8, at 1009-10; Dent, supra note 8, at 122-34; Coffee \& Schwartz, supra note 119 , at $331 \mathrm{n} .358$.

203. See, e.g., Abramowitz v. Posner, 672 F.2d 1025, 1030-31 (2d Cir. 1982); Mills v. Esmark, Inc., 544 F. Supp. 1275, 1282 (N.D. Ill. 1982); Zapata Corp. v. Maldonado, 430 A.2d 779, 784 n. 10 (Del. 1981).

204. Corporate Governance, supra note $120, \S 7.03(\mathrm{a})$.

205. Id. § 7.03(b).

206. Id. $\$ \S 7.06-7.10$.

207. Id. $\S 7.08$.

208. Id. § 7.12 . 
action or as a step toward the corporation's assuming control over the suit. ${ }^{209}$ On this point, the proposals appear infinitely sound. Certainly there is no suggestion in the materials reviewed earlier that structural bias is less robust when the so-called independent directors constitute a majority of the board (so that under contemporary standards a demand is required and a lower level of review occurs) than when only a minority of the board is considered independent (so that demand is excused).

The centerpiece of the proposals to the ALI is the prescreening of suits through the special litigation committee. ${ }^{210}$ The current philosophy of the proposals regarding the directors' capacity to be impartial in the prescreening procedure is most apparent by reviewing the dramatic changes the proposals have undergone during the project's brief history. The earliest proposals contained demanding threshold independence requirements for committee members. ${ }^{211}$ In subsequent drafts, such a prophylaxis was sacrificed, and protection from committee member bias was sought through allocating to the committee the burden of establishing the propriety of its recommendation. ${ }^{2: 2}$ The most recent proposals to the ALI reflect no outward concern that committees may act out of bias. ${ }^{213}$ Instead, they incorporate only loose independence requirements, ${ }^{214}$ and the assignment of the burden of proof is guided by inquiring who would have borne that burden of proof if a committee had not stationed itself between the plaintiff and the defendant. ${ }^{215}$

209. Id. at 53-55.

210. Id. at 5-6.

211. American Law Institute, Principles of Corporate Governance and Structure: Restatement and Recommendations $\$ 7.03(\mathrm{e})$ (Tent. Draft No. 1, 1982), imposed significant restrictions on the selection of committee members elected to the board after the suit was commenced. See also supra, text accompanying note 166. However, that draft did not concern itself with biasing through either the directors' association or cultural identity with the defendants.

212. American Law Institute, Principles of Corporate Governance: Analysis and Recommendations $\S \S 7.07-7.12$ (Council Draft No. 3, 1983). For criticisms of this draft, see Cox, supra note 123 , at $783-88$.

213. Corporate Governance, supra note 120 , at 103 .

214. Committee members are to be both independent and capable of an objective judgment of the suit. Id. $\$ 7.10(\mathrm{a})$. Independence concerns only the director's familial or monetary relationship to the suit or the defendants. American Law Institute, Principles of Corporate Governance: Analysis and Recommendations $\S 1.15$ (Tent. Draft No. 2, 1984). To date such relationships have rarely been found as the basis for disregarding a committee's dismissal recommendation. For a decision disregarding committee decision on such grounds, see Hasan v. CleveTrust Realty Investors, 729 F.2d 372 (6th Cir. 1984). The standard of whether directors can be expected to be objective is a potentially open-ended one which could be most useful in unearthing committee bias. On its potential scope, there is very little guidance from the case law and none from the proposal's commentary. Two cases in point are Miller v. Register \& Tribune Syndicate, Inc., 336 N.W.2d 709 (Iowa 1983), and Swenson v. Thibaut, 39 N.C. App. 77, 250 S.E.2d 279 (1978). Miller is not an ad hominem judgment of the committee's impartiality, as envisioned by the proposals to the ALI, however, but reflects the court's disapproval of the defendants' selection of their own committee. Miller therefore is inconsistent with the current proposals to the ALI. Swenson is distinguishable from Miller only by the fact that the committee members flaunted how superficial their independence was by voting against the derivative suit before they assumed their positions on the committee. An effective standard to unearth bias must surely be able to reach matters more subtle than those illustrated in Swenson. With the proposal's thesis that directors are not assumed to be biased, it is unlikely that the standard was intended to reach more subtle suggestions of bias.

215. Corporate Governance, supra note 120 , at 100-02. The committee does have the burden of proof both on the question of its members' being able to exercise impartial judgment and on the 
In general corporate parlance, the plaintiff has the burden of disproving the committee's recommendation where the substantive allegation implicates a fiduciary's duty of care; the committee shoulders that burden when the suit alleges a duty of loyalty which has not been otherwise independently authorized or ratified. The rationale for this treatment is simply that the interjection of a committee into the litigation is not believed to be a legitimate consideration for changing the substantive burdens of either the plaintiff or the defendant from what they would have been if no committee recommendation were before the court. ${ }^{216}$

The proposals, consistent with the quest for a prescreening device which will shorten litigation, envision that courts will uphold committee dismissal recommendations even when there are material differences in facts or law between the plaintiff and the defendant. ${ }^{217}$ For most cases, the focus of this inquiry will be the suit's expected value, ${ }^{218}$ the remoteness of a judgment adverse to the defendant, ${ }^{219}$ or the presence of significant costs collateral to the suit. ${ }^{220}$ These are all factors which borrow heavily from Joy's "worth" standard. Unlike Joy, however, which considered only whether the suit's costs exceeded its value, the proposals expand the committee's prerogatives by authorizing dismissal of suits which have positive expected values but whose probabilities of success are considered remote. ${ }^{221}$

The troubling aspect of the current proposals is not their treatment of who has the burden of proof or the standards by which the court is to evaluate the suit's worth. The proposals capture well the criteria against which a suit's continuance should be judged, and earlier parts of this article have not raised the allocation of the burden of proof as a reliable buffer to structural bias. ${ }^{222}$ What is worrisome is the proposal's thesis that the potential for structural bias

adequacy of its investigation. Id. $\$ 7.11(\mathrm{~b})$. These factors are not difficult to establish, however, and the allocation of the burden is not an important consideration to either party. See Cox, supra note 8 , at $976-78$.

216. The belief that the introduction of a special litigation committee should not change the substantive strengths and weaknesses of the transaction underlying the conflict was originally put forth in Buxbaum, Confict-of-Interests Statutes and the Need for a Demand on Directors in Derivative Actions, 68 CAlif. L. REv. 1122 (1980), which reasoned that, because modern conflict of interest statutes disable independent directors from retroactively approving self-dealing transactions, special litigation committees may not insulate such a transaction from suit. Id. But see Cox, supra note 8 , at 1003-05. Thus, the proposals to the ALI appear to have accepted Professor Buxbaum's reasoning but not his prescription.

217. See generally Corporate Governance, supra note 120, at 105-09.

218. Corporate Governance, supra note $120, \S 7.08(\mathrm{c})(2)$.

219. Id. $\$ 7.08(\mathrm{c})(1)$.

220. Id. $\$ 7.08(\mathrm{c})(4)$. The proposals are more permissive in this regard than was the Second Circuit in Joy, which would allow consideration of such indefinite considerations as reputational loss and deflection of employee time only if the expected recovery was not substantially greater than the suit's out-of-pocket costs. Joy v. North, 692 F.2d 880, 892 (2d Cir. 1982), cert. denied, 460 U.S. 1051 (1983). Two other more specific considerations enter into the court's decision. Dismissal can occur if, before the suit was initiated, the corporation had undertaken appropriate corrective or disciplinary action. Corporate Governance, supra note $120, \S 7.08(a)(3)(C)$. Dismissal is not appropriate under any grounds, however, if it will enable the defendant to retain an improperly received benefit. Id. $\$ 7.08(\mathrm{e})$.

221. Id. at 106-07.

222. See supra note 14. 
will not corrupt the committee. This assumption is expressed in the commentary $^{223}$ and underlies the proposal's conclusion that the burden of proof for the basis of the committee's recommendation is guided by the substantive character of the transaction challenged in the suit. We believe the appeal of this position is solely that it assures purity between substantive and procedural rules. It has little else to commend it to us. To argue that because independent director approval of a self-dealing transaction places the burden of proving waste on the plaintiff, and that, hence, an independent committee's review of that same transaction should similarly place the burden of proof on the plaintiff, operates on the false hope that the directors in each case are impartial in their assessment of the transaction, their colleague, and the suit. Earlier proposals followed the Zapata's approach of having sufficient distrust in the director's impartiality so that the burden of establishing the bases for their recommendation was placed upon the committee. We do not counsel a return to the Zapata-like approach. A prescreening process should not be premised on both distrust of committee members and the belief that judicial review can deal effectively with structural bias.

In condemning both the current proposals to the ALI and the Zapata-like approach, we suggest that the reviewing court's role is vastly different if it follows Zapata and envisions that its mission is to unearth evidence or suggestions of bias, from its role under the current proposals in which the court evaluates the persuasiveness of the report free of an underlying concern that its preparers are biased. For example, when the review is undertaken with both a healthy awareness of and concern for the many biasing agents which accompany the special litigation committee, incompleteness of the committee's investigation or inconsistencies in its report are themselves bases for disregarding the committee's dismissal recommendation. On the other hand, it is expecting too much and is even inconsistent with the premise of prescreening-that the proceeding be efficient-to demand that a committee's factual or legal conclusions be free of doubt or, for that matter, that its investigation be exhaustive. The proposals to the ALI reflect this view in their recognition that committee recommendations should be accepted in conflicts where facts or law are indeterminate and problematic. Under the proposals to the ALI, however, deficiencies are accounted for in deciding whether on balance the committee in a loyalty case sustained its burden of proof or the plaintiff in a duty of care suit failed to overcome the presumption of validity. Weaknesses in the current proposals are exacerbated by the procedural economies dictated by any prescreening procedure intended to foreshorten wasteful litigation. Even with the burden of proof, a committee in sole possession of the facts and on the offensive against the derivative suit can surely-especially with the aid of skilled counsel-prepare a convincing portrayal of the committee's perception of the suit which omits substantive conflicts or otherwise inadequately treats important issues. ${ }^{224}$ The plaintiff

223. Corporate Governance, supra note 120 , at 103.

224. Cf. id. at 73 . 
operates at a strategic disadvantage because he is constrained in terms of discovery and in the areas in which he may probe the committee's substantive determinations at a hearing. In this respect, it is relevant that in a large percentage of the post-Zapata cases, the plaintiff's attorney has not challenged the substance of a committee's report, so that judicial review has occurred without the plaintiff's input. ${ }^{225}$

Joy is distinguished as a rare case in which a court rejected a committee's dismissal recommendation by disagreeing with the substance of the committee's report. In Joy, however, the committee's report was rejected because of both blatant deficiencies and important internal inconsistencies. ${ }^{226}$ It remains to be seen whether, under the current proposals to the ALI, the committee's view of the suit's worth would have been accepted. Under the proposals, a court which has found a report deficient in some of its details, as in Joy, may nevertheless conclude that the deficiencies do not erode the overall force of the report. ${ }^{227}$ The court could reach this conclusion because the reviewing court's mission is not to unearth signs of structural bias, but to consider the report's assessment of the suit's value, likelihood of success, or presence of significant tangential costs. The overall effect, therefore, is that even a committee report which is incomplete or inconsistent will still be seen as the more complete and persuasive perception of the corporate interest served by the suit's continuance than the plaintiff's more "slender" version of the dispute. We believe the prescreening procedure currently before the ALI will be effective only if significant changes occur in the composition and selection of committee members.

\section{IV}

\section{Moving Beyond Intermediate Approaches}

Our criticisms of existing approaches to the directors' structural bias in their assessment of a colleague's alleged wrongdoing cannot be solved through narrow refinements in current derivative suit procedures. We reject the basic premises underlying the current roles of directors and courts in derivative suits.

225. See, e.g., Joy v. North, 692 F.2d 880 (2d Cir. 1982), cert. denied, 460 U.S. 1051 (1983)(plaintiff apparently allowed limited access to the committee's report yet presented no countervailing information in appeal of the district court's dismissal of the derivative suit); Abella v. Universal Leaf Tobacco Co., 546 F. Supp. 795, 802 (E.D. Va. 1982); see also supra note 175.

226. 692 F.2d at $894-97$.

227. In this regard, it is important that Joy was a suit involving the directors' alleged "care" violation, for which the plaintiff has the burden of proof on the substantive inquiries of the committee's performance under the proposals to the ALI; Joy, however, held that under Delaware law this burden was on the committee. 692 F.2d at 892 . For a case suggesting that in duty of care suits before a court historically thought to be most solicitous of managers and directors, even the unexpected may occur, see Smith v. Van Gorkom, 488 A.2d 858 (Del. 1985). The fear that the more sweeping investigation and findings of a committee may nevertheless overpower the more specific exceptions taken by the plaintiff is found in Mills v. Esmark, Inc., 544 F. Supp. 1275, 1284-88 (N.D. III. 1982), and Abella v. Universal Leaf Tobacco Co., 546 F. Supp. 795, 800-02 (E.D. Va. 1982). 
We believe that the foundations of director bias are much more robust than those recognized by Miller, ${ }^{228}$ Stein, ${ }^{229}$ and Zapata. ${ }^{230}$ We reasoned earlier that Miller offers no explanation why a fellow CEO selected by the court to judge the merits of a suit can be expected to be any more impartial than one selected by the directors. ${ }^{231}$ Stein's concern that a minority voice may be chastened toward conformity by a larger group implicitly recognizes the effect of a mutually attractive group, but the court's review of the directors' independence followed traditional lines of inquiry by focusing on their relation to the suit or the defendants, not their associations with the group. ${ }^{232}$ Similarly, Zapata reflects a concern that directors may be biased because of their own vulnerability to suit since their vocational positions are similar to those of the defendants. Zapata's response to this concern in the case of the special litigation committees was inadequate, ${ }^{233}$ and it held that no response whatever was needed in the case in which demand is not excused. ${ }^{234}$ Zapata can be seen as recognizing the potential for bias, but seeing its effects as more limited and of a lower impact than is suggested in the early section of this article.

In sum, we believe that court decisions as well as the proposal to the ALI have failed to reflect fully the psychological facts that colleagues are not naturally impartial when evaluating each other at the demand of an outsider. The ingroup bias among directors comes not solely because they have been handpicked by the defendants, or because they represent a smaller number than the defendants, or because they share similar positions. Rather, all of these and many more factors taken together drive them to each other's side.

For these reasons, we conclude that the derivative suit should be reformed so that the directors' recommendation regarding a suit's impact on the interests of the corporation would be disallowed whenever the suit implicates a colleague of the directors, be that colleague a fellow director, control person, or a senior executive who associates on a regular basis with the directors.

The removal of directors from their important and historic screening role necessarily sacrifices their unique perspective on those matters implicated by the suit that concern the conduct of the corporation's business, such as harm to ongoing business relationships, injury to reputation, and deflection of employee time. This sacrifice is not so great as it first would appear. First, the impact of the suit on such commercial considerations is not endemic to the derivative suit; they are present even in third party suits against corporate personnel. It is merely that procedural practice in the past has not allowed them to consider these factors in other types of litigation. This, while not a

228. See supra text accompanying notes 151-55.

229. See supra text accompanying notes 157-58.

230. See supra text accompanying notes 159-78.

231. 336 N.W.2d at 718 .

232. 531 F. Supp. at 693-95.

233. See Cox, supra note 8 , at $974-94$.

234. See 430 A.2d at 784 . 
sufficient justification for ignoring them in derivative suit litigation, does suggest that we may wish to consider whether these factors may be given suitable attention in a proceeding that is tailored to invite inquiry into the suit's costs and benefits and is not limited to the narrower issues of the suit's legal merits, as are contemporary motions for dismissal and summary judgment. More importantly, consideration of these costs is better viewed tangentially to evaluation of the suit's merits, an inquiry not uniquely within the directors' competence or sensitivity. That is, concerns for business relationships, injury to reputation, and deflection of employee time are of such an indefinite nature, in terms both of their magnitude and actual existence, as to be highly untrustworthy as pivotal considerations in deciding whether the derivative suit should go forward. These matters have greater force when the suit's merits have been seriously questioned, because the benefits of a potentially frivolous action are most attenuated, and matters of morale and reputation are most implicated, when the corporation's personnel are unjustifiably skewered in a derivative suit solely because of their corporate positions. On the other hand, when the suit's merits appear to be strong, these costs to the corporation achieve significance only when they are proportionately large vis-a-vis the expected recovery. ${ }^{235}$ Their consideration at this point, however, should be subject to the same standard of proof and persuasion as the challenges to the suit's merits.

In the context of screening derivative suits, the lawyer's analytical and forensic talents are of greater import than the directors' education, experience, and sensitivity; ${ }^{236}$ the directors' unique contribution is made not in the area of persuasion, but in the guidance they can give counsel in identifying potentially sensitive areas implicated by the derivative suit. Similarly, a broadly drafted pretrial screening procedure will permit the directors to provide their own interpretation of a business transaction without requiring that they serve on the committee empanelled to evaluate the transaction that is the subject of the derivative suit's complaint. The medium for this investigative inquiry, therefore, need not be through a committee of the defendant's colleagues. The special litigation committee should continue as the investigative vehicle to review the derivative suit complaint's allegations both in terms of law and facts. But the committee's members should be

235. This approach was prescribed by Judge Winter in Joy v. North, 692 F.2d at 892 (2d Cir. 1982), cert. denied, 460 U.S. 1051 (1983). In duty of loyalty cases, the proposals to the ALI prevent the corporation's litigation costs from causing the suit's dismissal, because the court may impose these costs on the defendants who have breached their fiduciary obligations to the corporation. Corporate Governance, supra note $120, \S 7.16$ (d) comment $\mathrm{f}$, at 196.

236. All evidence suggests that the committee members' contribution both in terms of time and substantive contribution pales in comparison to that of the committee's counsel. In a recent case, for example, the members of the committee devoted all or a part of 35 days to examining the derivative suit, whereas the committee's counsel logged 5000 hours in the case. Kaplan v. Wyatt, 484 A.2d 501 , 511,515 (Del. Ch. 1984). See also Rosengarten v. International Tel. \& Tel. Corp., 466 F. Supp. 817 , 824 (S.D.N.Y. 1979), and DeMott, Defending the Quiet Life: The Role of Special Counsel in Director Terminations of Derivative Suits, 56 Notre Dame Law. 850, 863-67 (1981). 
appointed by the court ${ }^{237}$ and should not include any of the defendants' colleagues (past or prospective) or even those likely to share a cultural identity with the defendants. Rather, the committee should consider, among other things, the input of corporate personnel, including current board members, on the likely commercial impact of the derivative suit.

We believe the court should continue to be the final voice on whether the corporate interest is served by continuing the derivative suit. The court's opinion, however, should be formed in light of a committee's investigation of the complaint's allegations which allows modest input from the litigants. With the committee comprised of members not likely to share a cultural identity or associations with the defendants, the court would focus not on signals of collegial bias, but on the soundness of the complaint's allegations in light of the law and facts presented by the committee. Considerations of efficiency require that the judicial proceeding be an abbreviated one, so that some distrust will necessarily arise concerning whether the committee's investigation considered all factual matters and whether the plaintiff was permitted sufficient discovery to meet any negative aspects of the committee's report. Because the committee will be cleanly sheared of collegial and cultural identity with the defendants, however, there will be no cause to believe that any such deficiencies will be systematically biased against the plaintiff. Moreover, it would appear logical to place the burden of persuasion on the committee to challenge the derivative suit complaint as failing to establish a serious potential for serving the corporation's interest. This burden appears reasonable because the focus of the hearing is on evaluating the complaint, not on establishing the defendant's defense.

\section{Conclusion}

The approach we recommend responds to the need for a prescreening of derivative suits to overcome the potentially corrupting incentives ${ }^{238}$ that pervade representative suit litigation as well as the harm that an ill-advised suit can cause the corporation's stockholders. At the same time, it seeks to deal with those social and psychological forces that have blinded directors in their quest to serve the corporation's interests when rendering a recommendation concerning a derivative suit. We have responded to these concerns by removing the defendants from the appointive process, by seeking

237. The court has the power to appoint a committee, under the proposals to the ALI, only when requested by the corporation; but that proposal contains none of the membership constraints recommended above. See Corporate Governance, supra note $120, \S 7.12$.

238. Professor Coffee reasons, in his article published in this issue, that the vitality of the derivative suit is unaffected by the presence of the special litigation committee, because the threat that device poses to the suit has merely the effect of reducing the suit's settlement value to an amount below the cost of a special litigation committee investigation and report. Coffee, supra note 134, at 31-32. This reasoning overlooks both the fact that it is the corporation's money which funds the committee's work and the fact that defendants can be expected to prefer absolution to settlement, especially when the former carries no additional cost to themselves. 
members who are not the defendants' colleagues, and by urging sensitivity to the committee members' cultural background. Each of these are today powerful forces which cause directors to edit the decision choice posed by the derivative suit so as to give insufficient consideration, if any, to the derivative suit's upside potential. Whatever the ultimate refinements in either the demand requirement or special litigation committee, they must be sensitive to these concerns and must, we believe, conform at least minimally to the review procedures described above. Current procedures are gravely deficient in addressing the malady of boardroom bias which if unremedied threatens the continued vitality of the derivative suit. 
